\begin{tabular}{lllll}
\hline |ljciprod01 $\mid$ productn $\backslash \mathrm{C} \backslash \mathrm{CPY} \backslash 58-4 \backslash \mathrm{CPY} 404 . t x t$ & unknown & Seq: 1 & 31-OCT-11 & 11:23 \\
\hline
\end{tabular}

Protection of Traditional Knowledge

401

\title{
PROTECTION OF TRADITIONAL KNOWLEDGE: TRADE BARRIERS AND THE PUBLIC DOMAIN
}

\author{
DAVid R. HANSEN*
}

In recent years, developing nations have pushed for international copyright and other intellectual property regimes to expand protection over the cultural heritage and collective knowledge of particular indigenous groups, which includes works typically protected by copyright such as visual art, storytelling, dance, and music. These "traditional knowledge" protections have been justified by factors like economic protection, equity in intellectual property ownership, cultural protection, and economic development. These motivating factors are a far cry from the underpinnings of traditional Western intellectual property law - and in particular, U.S. copyright law which focuses on incentivizing the creation of new content for the promotion of "the Progress of Science and useful Arts." Because of these differing justifications, traditional knowledge protections at the international level have generated some degree of friction between the developed and the developing world. So far, much of the debate focuses on the "political" and "real" costs and benefits of traditional knowledge rights, but there is little discussion of the legal consequences of current protections. Given the underlying ideological conflict, some legal dissension is likely to occur regarding enforcement and protection of traditional knowledge rights.

This article examines "positive" traditional knowledge protections, which provide copyright-like rights over content, including the right to exclude, license, and profit from these works. In many cases these protections regulate works that Western eyes would view as in the public domain. Initiatives to provide international protection for traditional knowledge expressions have blithely proceeded without much regard for the potential consequences under existing international law. This article makes the point that at least

*David Hansen is currently the Digital Library Fellow at the University of California, Berkeley School of Law. In this position he is broadly tasked with identifying and addressing copyright and other legal issues that confront libraries. Before joining Berkeley Law, he addressed legal and policy issues related to open access and academic authorship in Duke University Libraries' Office of Scholarly Communication. While there, he attended the University of North Carolina at Chapel Hill, School of Information and Library Science, and expects to receive a Master of Science in Library Science from UNC Chapel Hill in May 2012. David holds a J.D. from the University of North Carolina at Chapel Hill, School of Law and a B.S. in Economics from the University of North Carolina at Charlotte. Thanks to Lolly Gasaway and Kevin Smith for their many comments and suggestions on this article. All errors are my own. 


\begin{tabular}{lllll}
\hline |ljciprod01 $\mid$ productn $\backslash \mathrm{C} \backslash \mathrm{CPY} \backslash 58-4 \backslash \mathrm{CPY} 404 . t x t$ & unknown & Seq: 2 & 31-OCT-11 & 11:23 \\
\hline
\end{tabular}

some existing traditional knowledge protections not only conflict with IPpolicy norms of the United States and the European Community, but also that these protections may violate the very terms of TRIPs and GATT. As work toward international protection of traditional knowledge progresses, policy makers should be aware of these legal incompatibilities and how they evidence the deep conflict between expansive traditional knowledge protections and Western IP policy.

\section{CONTENTS}

INTRODUCTION ............................... 402

I. DEFINING TRADITIONAL KNOWLEDGE AND ITS

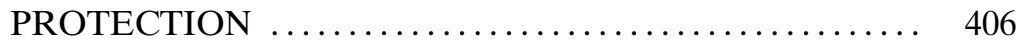

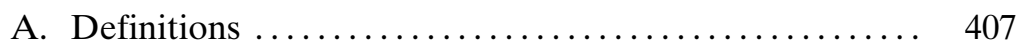

B. Protection ............................... 412

II. MOTIVATIONS FOR PROTECTION .............. 415

A. Motivations for Classic Copyright Protection ......... 417

B. Motivations for TK Protection .................... 419

C. Whose Public Domain? ........................ 423

III. WORKING WITHIN THE WTO ................ 426

A. The GATT "Filter" of Prohibiting Disguised

Restrictions on Trade ....................... 427

B. TRIPS as a Maximum-Rights Treaty ........... 428

1. Preamble, Principles, and Objectives of TRIPS ... 430

2. Procedural Enforcement .................... 431

CONCLUSION ................................... 437

$\mathbf{R}$

\section{INTRODUCTION}

Jeremy Tarr first traveled to Guinea in May 1999, wanting to learn the traditional music and arts of the Guinean people. ${ }^{1}$ While there, he sought out and studied under Koumgbana Conde, the Artistic Director of Les Percussions de Guinee (National Percussion Ensemble of Guinea). For over five years, Jeremy studied under Koumgbana as his mentee, traveling from the United States to Guinea for three-month periods to study and practice his art. While in Guinea he learned the traditional beats and dance of Guinea such as Kassa, Soko, Dundunba, Soli, and Lamban, which he brought back to the United States. He also brought back drummers, dancers and bala players, all of whom helped him start a successful

1 Jeremy Tarr is a friend of the author and a judicial clerk at the Supreme Court of North Carolina. The following description is based on an interview with Jeremy Tarr on November 19, 2010, along with follow-up questions in an email dated December 1, 2010 (on file with author). 


\begin{tabular}{lllll}
\hline |ljciprod01 $\mid$ productn $\backslash \mathrm{C} \backslash \mathrm{CPY} \backslash 58-4 \backslash \mathrm{CPY} 404 . t x t$ & unknown & Seq: 3 & 31-OCT-11 & 11:23 \\
\hline
\end{tabular}

dance company, Ballet Warraba, which performed traditional music and dance from Guinea.

Traditional knowledge can be acquired in many ways; Jeremy's experience is in no way typical, since there really is no typical method of acquiring such varied and diverse content. Although only a small subset of the domain of traditional knowledge, the cultural expressions that Jeremy experienced (and works that this article is primarily concerned with) can include a wide variety of visual art, music, dance, and storytelling - works that likely would be subject to copyright protection if they met copyright's authorship and originality requirements.

But Jeremy's experience does illustrate the historically-typical high costs of acquiring traditional knowledge. He studied for years, spent countless hours traveling, learned a new language, and lived among parts of the Guinean community for months at a time. His investment in the Guinean community was significant, yet he took back with him a significant amount of traditional Guinean knowledge as well. But today, traditional knowledge like the kind Jeremy acquired while in Guinea - along with all sorts of other knowledge - is susceptible to quicker, easier, and cheaper duplication. Cell phone cameras, wireless internet, and smaller and more compact recording devices all contribute to the ease with which one can appropriate particular cultural expressions.

While those technologies cannot duplicate the entire experience of learning and understanding a particular culture or community, they do allow for the exportation of at least some important elements of cultural expressions. Perhaps this is one reason why there has been a renewed push for international protection of traditional knowledge. Protection of traditional knowledge has been a component of national laws and a recognized issue for decades, but the debate over international protection has received renewed attention. National laws granting traditional knowledge protection have now been followed by regional initiatives and proposed international enforcement mechanisms. ${ }^{2}$

2 A recent regional initiative of note is the African Regional Intellectual Property Organization's (“ARIPO”) Swakopmund Protocol. See Swakopmund Protocol on the Protection of Traditional Knowledge and ExPRESSIONS OF FolkLORE (ARIPO Swakopmund, Namibia 2010), available at http://www.aripo.org/images/Swakopmund_Protocol.pdf.

Other proposed international or regional harmonizing initiatives date back to the 1970s. See United Nations Educ., Scientific \& Cultural Org. (UNesCO), World Intell. Prop. Org., Tunis Model Law on CopyRight for Developing Countries (1976) (WIPO Pub. No. 812(E)), available at http://portal.unesco.org/culture/en/files/31318/11866635053tunis _model_law_en-web.pdf/tunis_model_law_en-web.pdf; UNITED NATIONS Educ., Scientific \& Cultural Orgs. (UNESCO) \& World Intell. Prop. Org.; Model Provisions for National Laws on the Protec- 
In October 2000, the World Intellectual Property Organization ("WIPO") established the Intergovernmental Committee on Intellectual Property and Genetic Resources, Traditional Knowledge and Folklore ("IGC"), with the goal of, among other things, elaborating on "an international framework for traditional knowledge protection, and the development of a system of 'community' or 'collective' rights to protect traditional knowledge." 3 Since then, the IGC has produced a number of reports and has generated draft legal instruments for the harmonized international protection of traditional knowledge ("TK"), traditional cultural expressions ("TCE"), and genetic resources. ${ }^{4}$ These harmonized TK protections are fundamentally different from previous harmonization initiatives; international harmonization of various intellectual property rights ("IPR"s) has been a long-standing WIPO objective, but it has focused largely on classic IPR systems such as copyright, trademark, and patent.

The United States and the European Community have long been in the position of leading the charge for the upward harmonization of IPRs where those IPRs protect content produced within their jurisdictions; thus their recent support for the push toward stronger harmonized enforcement mechanisms (commonly referred to as TRIPs-plus) to prevent counterfeit and pirated works comes as no surprise. ${ }^{5}$ But any benefit from international TK protections would flow almost entirely to the developing world. Perhaps more troubling to the global North is the fact that many of these TK protections are fundamentally at odds with information policy and legal traditions of the European Community and the United States.

Tion of Expressions of Folklore Against Illicit Exploitation And Other Forms of Prejudicial Action, 1982 (1985) (WIPO Pub. No. UNESCO001), available at http://www.wipo.int/wipolex/en/details.jsp?id= 6714; Bangui Agreement Relating to the Creation of an African Intellectual Property Organization, Constituting a Revision of the Agreement Relating to the Creation of an African and Malagasy Office of Industrial Property, Mar. 2, 1977, (entered into force Feb. 8, 1982), revised Feb. 24, 1999 (entered into force Feb. 28, 2002), available at http://www.wipo.int/wipolex/en/ other_treaties/details.jsp?treaty_id=227.

3 World Intell. Prop. Org., Matters Concerning Intellectual Property \& Genetic Resources, Traditional Knowledge \& Folklore (Aug. 25, 2000) (7, WO/GA/ 26/6), available at http:/www.wipo.int/edocs/mdocs/govbody/en/wo_ga_26/ wo_ga_26_6.pdf.

4 For the text of these drafts and documentation on their development, see Intergovernmental Committee, World Intell. Prop. Org. (last visited Dec. 5, 2010), http://www.wipo.int/tk/en/igc.

5 The United States, and to a lesser extent the European Community, have been leaders in the push for various "TRIPs-plus" enforcement mechanisms that will enhance protections for copyrighted and trademarked goods. See, e.g., Consolidated Text - Anti-Counterfeiting Trade Agreement, Informal Predecisional/Deliberative Draft: (Oct. 2, 2010 2010), available at http:// trade.ec.europa.eu/doclib/docs/2010/october/tradoc_146699.pdf. 


\begin{tabular}{lllll}
\hline |ljciprod01 $\mid$ productn $\backslash \mathrm{C} \backslash \mathrm{CPY} \backslash 58-4 \backslash \mathrm{CPY} 404 . t x t$ & unknown & Seq: 5 & 31-OCT-11 & 11:23 \\
\hline
\end{tabular}

Copyright and patent protections are based on the presumption that the exclusive rights they grant are incentives to innovation and creation, and that those protections will provide a just reward for the intellectual labors of the author or inventor. TK protections do not have such elegant theoretical backing. Rather, TK protections are the result of a combined effort to synthesize the high points of disparate local and customary laws, facilitate the prevention of unwanted uses of resources by those outside the TK community (e.g., for sacred or spiritually significant items), to correct North-South information and economic inequity, and to spur economic development. ${ }^{6}$ At the December 2009 WIPO Regional Seminar on TK protections, the opening presenter from Indonesia made the basic point: "If the knowledge assets of developed countries are internationally protected, why [are] the developing countries' ... not?"7

This article explores how the motivating factors for TK protection compare to those of U.S. and European style IPRs. Specifically, it examines TK protections which grant exclusive (i.e., "positive") rights over particular expressions, thereby approximating the rights granted by classic copyright, and how the justification for those rights differ from classic copyright. Various commentators have already weighed in on the real costs and benefits of these positive TK protections - that is, whether TK protection will have an overall benefit on the protection, preservation, and exploitation of TK itself. Somewhat controversial, these debates revolve around a number of difficult ideological and, to some extent, unanswerable questions about the nature of knowledge itself. ${ }^{8}$

Rather than reargue those same points, this article points out these basic objections of the global North to TK protections in order to highlight the points on which legal objections to TK protection may be made. Because of the dramatic ideological differences regarding the purposes of IPRs, some discussion of the real costs of TK protection is needed to inform this discussion. Given the United States and European Community's position on international recognition of TK protections, it is unlikely that

6 These motivating factors are discussed at length infra Part II (Motivations for Protection).

7 Damos Dumoli Agusman, Director, Legal Affairs and Treaties on Economic, Social and Cultural Affairs, Department of Foreign Affairs, Republic of Indonesia, Topic 1: An Introduction to Core Concepts and Objectives: What Are Traditional Knowledge (TK), Genetic Resources (GRs) and Traditional Cultural Expressions (TCEs)? Why Should They Receive Legal Protection? (Dec. 16, 2009) (WIPO/IPTK/BKK/09/TOPIC1/1), available at http://www.wipo.int/ edocs/mdocs/tk/en/wipo_iptk_bkk_09/wipo_iptk_bkk_09_topic1_1.pdf.

8 See infra Part II(B) (discussing the ideological debate and the long-term costs and benefits of TK protections). 
either will agree to strong WTO-level TK protections. ${ }^{9}$ There is movement afoot, however, to strengthen international TK protection either through stronger regional instruments or through a less formal WTO "declaration," both of which may impact trade with the United States and the European Community. It is therefore feasible that these countries may look to the WTO trade dispute resolution system, which in turn will be forced to interpret the relevant provisions of the General Agreement on Tariffs and Trade ("GATT") and the Agreement on Trade-Related Aspects of Intellectual Property Rights ("TRIPs"). ${ }^{10}$ While a number of commentators have already made the point that TK protections are largely outside the protective bounds of TRIPS, ${ }^{11}$ this article goes one step further and argues that at least some national or regional forms to TK protections are susceptible to attack as violating the current terms of both GATT and TRIPs as unreasonable restraints on trade. For U.S. and European policy makers, this susceptibility may bolster their argument against strong international protection of positive TK rights.

The article proceeds as follows: First, it outlines what is meant by the term "traditional knowledge protections," focusing on copyright-like protections of particular TK expressions. Second, it highlights the competing motivations for classic copyright protection and the motivations for TK protection, highlighting the conflicts between the two. This section specifically addresses authorship and the concept of the public domain in the traditional knowledge context. Third, the article examines the potential legal arguments against TK protections under TRIPs and GATT. The article concludes that at least some TK protections may run afoul of TRIPs and GATT, and that enforcement of those positive TK rights may be a disruption of trade itself.

\section{DEFINING TRADITIONAL KNOWLEDGE AND ITS PROTECTION}

This section gives a summary of what is meant by "traditional knowledge" in various contexts. The "definitions" provided here are meant to

9 See infra Part II(B).

10 General Agreements on Tariffs and Trade - Multilateral Trade Negotiations (The Uruguay Round): Agreement on Trade-Related Aspects of Intellectual Property Rights, Including Trade in Counterfeit Goods, Annex 1C, Dec. 15, 1993, 33 I.L.M. 81 (1994) [hereinafter TRIPs Agreement]; General Agreement on Tariffs and Trade, Oct. 30, 1947, 61 Stat. A-11, 55 U.N.T.S. 194 [hereinafter GATT]. The WTO is the now-relevant body and authority for interpreting GATT. See Final Act Embodying the Results of the Uruguay Round of Multilateral Trade Negotiations, Apr. 15, 1994, 33 I.L.M 1125, 1144 (1994) [hereinafter WTO Final Act].

11 See infra Part II(A) (detailing how TK protections do not fit within the traditional bounds of Copyright as protected under TRIPs). 


\begin{tabular}{lllll}
\hline |ljciprod01 $\mid$ productn $\backslash \mathrm{C} \backslash \mathrm{CPY} \backslash 58-4 \backslash \mathrm{CPY} 404 . t x t$ & unknown & Seq: 7 & 31-OCT-11 & 11:23 \\
\hline
\end{tabular}

be descriptive of the types of content that TK embraces, and are in no way technical or exhaustive. This section also outlines the basic terms of TK protection, focusing on those protections that are most likely to conflict with classic copyright motivations.

\section{A. Definitions}

"Traditional knowledge" is a broad term that covers "economic and cultural assets of indigenous and local communities and their countries." 12 Discussions of TK have focused on the traditions or practices of a particular community, and have drawn on the existing customary law that surrounds those traditions and practices. ${ }^{13}$ Because those practices vary so much, TK is sometimes defined by the very heterogeneity of its subject matter; a sort of miscellaneous category of intellectual property ("IP") for those who have missed out on traditional copyright, patent, or trademark protection. Because of the variety of ideas and expression that the term is thought to embody, it has been difficult to talk about in the abstract. ${ }^{14}$

12 Traditional Knowledge, Genetic Resources and Traditional Cultural Expressions/Folklore, World InTELl. Prop. OrG., http://www.wipo.int/tk/en (last visited Dec. 5, 2010).

13 See, e.g., World Intell. Prop. Org., Customary Law \& the Intellectual Property System in the Protection of Traditional Cultural Expressions \& Traditional KnOwledge (2006), available at http://www. wipo.int/export/sites/www/tk/en/consultations/customary_law/issues-revised.pdf (examining themes of customary laws and the possibility of harmonization). A number of commentators argue that traditional knowledge should stand in a class by itself under sui generis ("of its own kind") protections. See, e.g., Graham Dutfield, TRIPS-Related Aspects of Traditional Knowledge, 33 Case W. Res. J. InT'L L. 233, 240 (2001). Dutfield, for one, notes that there are two prevalent conceptual approaches to defining traditional knowledge: the first being to avoid definition altogether, simply adopting the position that traditional knowledge is "the knowledge held by traditional peoples and communities." Id. The other approach is "to deny that there is such a thing as [traditional knowledge]; to argue essentially that there is just knowledge." Id. Dutfield, however, takes the position that traditional knowledge "does exist and that it has both similarities and differences with the scientific knowledge of western and westernized societies." $I d$. This article asserts that there is "just knowledge," if just to make the point that all knowledge - North, South, traditional, or scientific - will be analyzed along the same lines in policy debates: who made it, who uses it, why did they do so, and what will cause them to protect it and create more of it? This is important for a practical assessment of how classic IPRs like copyright relate to traditional knowledge.

14 See World Intell. Prop. Org., Pub No. 920(E), Intellectual Property \& Traditional Knowledge 4 (2005) ("No single definition would fully do justice to the diverse forms of knowledge that are held by traditional communities; and no form of legal protection system can replace the com- 
Some define the term as simply "knowledge, possessed by indigenous people," 15 - a construct that is useful in that it identifies a central concern of traditional knowledge protection schemes: the protection of knowledge for the benefit of a particular group. ${ }^{16}$ Indeed, the IGC draft text of an international instrument for protection of TCE provides that benefits flow to members of particular communities by virtue of their membership in those communities. ${ }^{17}$ While this construct is useful, it is also ambiguous. What, for example, is the "community"; who are "indigenous people"? As discussed below, these terms are sometimes defined in national legal instruments. But more often than not, they remain intentionally flexible, and therefore vague. ${ }^{18}$

Another way to define "traditional knowledge" is to focus on its particular uses. For example, some use "traditional knowledge" to talk about traditional cultural expressions used in dances or paintings, ${ }^{19}$ while others

plex social and legal systems that sustain TK within the original communities.").

15 Srividhya Ragavan, Protection of Traditional Knowledge, 2 Minn. InTELL. Prop. Rev. 1, 4 (2001). For purposes of discussing the motivations for traditional knowledge protections, it is interesting to note that Ragavan goes on to identify "indigenous peoples" as "people who characteristically exist under conditions of severe disadvantage relative to others within the states constructed around them." Id.

16 The IGC draft international provisions for international traditional cultural expressions ("TCE") provides that beneficiaries of TCE protection should be defined as those " indigenous peoples and communities . . . and other cultural communities ... or the countries, to which a traditional cultural expression/expression of folklore is specific (a) in whom the custody, care and safeguarding of the TCEs/EoF are [entrusted] existing in accordance with their customary law . . . ; and (b) who maintain, control, use or develop the traditional cultural expressions/expressions of folklore as being [characteristic,] authentic and genuine of their cultural and social identity and cultural heritage." Intergovernmental Committee on Intell. Prop. and Genetic Resources, Traditional Knowledge and Folklore \& World Intell. Prop. Org., The Protection of Traditional Cultural ExPressions/Expressions of Folklore: Revised Objectives \& PrinciPLES, annex at 20 (Sep. 21, 2010) (WIPO/GRTKF/IC/17/4), available at http://www.wipo.int/edocs/mdocs/tk/en/wipo_grtkf_ic_17/wipo_grtkf_ic_17_ 17 Id. 4.pdf [hereinafter Protection of Traditional Cultural Expressions].

18 See infra Part I(B) (protections).

19 Many examples of national legislation take this focus. See, e.g., Copyright Act, ch. 68, Laws of the Federation of Nigeria 1990 art. 28(5), which provides: "[F]olklore" means a group-oriented and tradition-based creation of groups or individuals reflecting the expectation of the community as an inadequate expression of its cultural and social identity, its standards and values as transmitted orally, by imitation or by other means including:

(a) folklore, folk poetry, and folk riddles;

(b) folk songs and instrumental folk music; 


\begin{tabular}{lllll}
\hline |ljciprod01 $\mid$ productn $\backslash \mathrm{C} \backslash \mathrm{CPY} \backslash 58-4 \backslash \mathrm{CPY} 404 . t x t$ & unknown & Seq: 9 & 31-OCT-11 & 11:23 \\
\hline
\end{tabular}

use the term to include traditional methods or processes (such as agricultural techniques) that have been developed over time. ${ }^{20}$ "Traditional knowledge" as a top-level term has been generally subdivided along these lines, split into the narrower categories of "traditional cultural expressions" ("TCE"), "genetic resources," and "traditional knowledge," which appears to be a sort of miscellaneous of the miscellanea category. ${ }^{21}$ Much of the literature focuses on genetic resources and the biological and medicinal aspects of traditional knowledge, ${ }^{22}$ because of its far reaching impact on biological diversity and the environment. ${ }^{23}$ The Convention on Biological Diversity takes a community-defined definition of TK one step further

(c) folk dances and folk plays;

(d) productions of folk art in particular, drawings, paintings, carvings, sculptures, pottery, terracotta, mosaic, woodwork, metalwork, handicrafts, costumes, indigenous textiles.

20 India, for example, has created strong "defensive" protection to keep traditional cultural methods free from excessive rights in third parties. See Shubha Ghosh, Traditional Knowledge, Patents, \& the New Mercantilism (Part I), 85 J. Pat. \& Trademark Off. Soc'y 828 (2003); Madhavi Sunder, The Invention of Traditional Knowledge, 70 LaW \& Contemp. Probs. 97 (2007).

21 See, e.g., Panel II: The Law and Policy of Protecting Folklore, Traditional Knowledge, and Genetic Resources, 12 Fordham Intell. Prop. Media \& ENT. L.J. 753, 756 (2002) ("[F]olklore was an archaism with the negative connotation of being associated with the creations of lower or superseded civilizations, so some developing country people do not like the word 'folklore.'"). This article avoids the semantic issue by using the term "traditional knowledge expressions." See also World Intell. Prop. Org, supra note 14 , at 4 .

22 The IGC has conducted a number of studies on genetic resources, and has generated a draft international legal instrument for their protection. See World Intell. Prop. Org., Intergovernmental Committee on Intellectual Property and Genetic Resources, Traditional Knowledge and Folklore, Genetic Resources: Revised List of Options AND FaCTUAL UPDATE (Sept. 15, 2010), available at http://www.wipo.int/ edocs/mdocs/tk/en/wipo_grtkf_ic_17/wipo_grtkf_ic_17_6.pdf. See generally Convention on Biological Diversity (2010), available at http://www. cbd.int.

23 The protection of biological and genetic resources is a hotly contested issue. In addition to the push for international protection of TK expressions, there are proposals to amend TRIPs to add a mandatory disclosure requirement for TK that would facilitate the identification and preservation of biological and genetic resources. See World Trade Org., Council for Trade Related Aspects of Intellectual Property Rights, Minutes of Meeting Held in the Centre William Rappard on 27-28 October and 6 November 2009, IIII 65-99 (IP/C/M/61) (2009); see also World Intell. Prop. Org., Draft Intellectual Property Guidelines for Access and Equitable BenefitShARING (July 30, 2004) (WIPO/GRTKF/IC/7/9), available at http://www. wipo.int/meetings/en/doc_details.jsp?doc_id=32239. 
and approaches traditional knowledge for a particular purpose: "knowledge, innovations and practices of indigenous and local communities embodying traditional lifestyles relevant for the conservation and sustainable use of biological diversity." 24 Many of these uses of traditional knowledge involve concerns which extend far beyond just information policy, and which involve serious biological and medical concerns.

For purposes of comparison to the IPR systems of the United States and, to a lesser extent, Europe, this article focuses on the protection of particular traditional knowledge expressions rather than processes or methods. These expressions are mostly commonly in the form of Traditional Cultural Expressions ("TCE") or Folklore. ${ }^{25}$ The term "traditional knowledge expressions" as used in this article is intended to capture TCEs and folklore, but also significant TK expressions which are not artistic but nevertheless are subject to the same concerns regarding authorship and originality when compared to classic copyright regimes. This focus is justified for two reasons: (1) the comparison to classic IPRs like copyright is simpler; and (2) there are fewer "external" concerns outside of the information policy realm, allowing a clearer view of how U.S. and European IP policy and tradition conflict with TK protections.

The first reason to focus on TK expressions is because the analysis is much simpler. Comparing traditional knowledge expressions to expressions that are copyrightable in other systems is fairly straightforward. Most countries (at least those that are members of TRIPS) merely require some form of authorship to achieve copyright protection for a particular expression. ${ }^{26}$ This relatively low standard is justified by the fact that a

24 Convention on Biological Diversity art. 8(j), opened for signature June 5, 1992, 31 I.L.M. 818 (entered into force Dec. 29, 1993) [hereinafter Convention on Biological Diversity].

25 Note that WIPO uses the term "traditional cultural expression" (or, "expressions of folklore"), which includes "music, art, designs, names, signs and symbols, performances, architectural forms, handicrafts and narratives." Traditional Cultural Expressions (Folklore), World Intell. Prop. Org. (2010), http://www.wipo.int/tk/en/folklore. There is some debate over the appropriate scope of the term, and some have criticized the use of "folklore" as devaluing the underlying content. See supra note 21(discussing criticism of the term "folklore" and adopting "traditional knowledge expressions" to avoid sensitive issues.

26 Although not entirely clear standing alone, TRIPs defines copyright protection to extend "to expressions and not to ideas, procedures, methods of operation or mathematical concepts as such." TRIPs Agreement art. 9(2). The Berne Convention (which all TRIPs members must adhere to), TRIPs Agreement art. 9(1), protects the "rights of authors in their literary and artistic works." Berne Convention for the Protection of Literary and Artistic Works art. 1, Sept. 9, 1886, as revised at Paris on July 24, 1971, and amended on Sept. 28, 1979, S. Treaty Doc. No. 99-27, 1161 U.N.T.S. 3 


\begin{tabular}{lllll}
\hline |ljciprod01 $\mid$ productn $\backslash \mathrm{C} \backslash \mathrm{CPY} \backslash 58-4 \backslash \mathrm{CPY} 404 . t x t$ & unknown & Seq: 11 & 31-OCT-11 & 11:23 \\
\hline
\end{tabular}

very narrow category of work is being protected-only one particular expression in one particular format. ${ }^{27}$ The protection of a process, manufacture, composition of matter or machine or other patentable subject matter is usually more complicated. Thus, TK that is not fixed or fixable as a copyrightable expression, but is arguably similar to patentable subject matter, would require discussion of whether it is (i) novel, (ii) non-obvious, and (iii) useful. ${ }^{28}$ While both copyright and patent rights can be difficult to establish on the fringes, copyright is by far an easier analysis because it only requires proving certain "structural" aspects of the work (i.e., a fixed medium of expression that is communicable to others) plus a minimal showing of originality; ${ }^{29}$ the actual merits of the creative work are for the most part irrelevant..$^{30}$

At a less superficial level, the second reason to focus on particular expressions rather than on broader patent-like subject matter is that protection of TK expressions allows for an analysis of pure information-policy aspects of copyright. TK expressions are a much smaller, and much less controversial, subset of the range of concepts covered by traditional knowledge. The stakes are simply higher for genetic and biological resources, as policy makers must consider not only the legal and theoretical requirements for protection, but also the myriad external policy concerns

[hereinafter Berne Convention]. Berne protections do not necessarily extend to expressions that are not fixed. Berne Convention, art 2(2) ("It shall, however, be a matter for legislation in the countries of the Union to prescribe that works in general or any specified categories of works shall not be protected unless they have been fixed in some material form.").

27 See, e.g., 17 U.S.C. § 102 (2006) (extending copyright protection to "original works of authorship fixed in any tangible medium of expression"); see also TRIPs Agreement art. 9(2) ("Copyright protection shall extend to expressions and not to ideas, procedures, methods of operation or mathematical concepts as such.”). Of course, copyright law may extend protection of an initial expression in another format by granting exclusive rights to prepare derivative works. See, e.g., 17 U.S.C. $\$ 106$ (2006) ("[T]he owner of copyright under this title has the exclusive rights to do and to authorize any of the following .... (2) to prepare derivative works based upon the copyrighted work.").

28 See, e.g., 35 U.S.C. $\$ \S 101-103$ (2006) (establishing the requirements for the patentability of inventions).

29 See 17 id. $\$ 102$ (2006) (fixed and communicable expression requirement); Feist Publ'ns, Inc. v. Rural Tel. Serv. Co., 499 U.S. 340, 346-47 (1991) (explaining that "[o]riginality is a constitutional requirement," and that "originality requires independent creation plus a modicum of creativity").

30 See Bleistein v. Donaldson Lithographing Co., 188 U.S. 239, 251 (1903); David E. Shipley, A Dangerous Undertaking Indeed: Juvenile Humor, Raunchy Jokes, Obscene Materials and Bad Taste in Copyright, 98 Ky. L.J. 517, 519 (explaining the principle of "aesthetic non-discrimination" as introduced by Justice Holmes in Bleistein). 
- many of which require scientific study - that come with protection. ${ }^{31}$ While traditional knowledge expressions are certainly important, their continuance is not, as the Convention on Biological Diversity puts it, "sustaining life on earth," as are many genetic resources. 32

One final reason to focus on TK expressions in particular is because, oddly enough, these expressions tend to be subject to much more restrictive controls than are genetic resources or other types of TK. Protections for genetic or biological resources have employed many "defensive" measures, such as database registries of existing TK, which serve as a prior art. These protections prevent the grant of patents over inventions that are not novel either because they have been used in traditional settings or because they are occurring naturally. ${ }^{33}$ As explained below, TK expressions are often protected through positive rights, granted exclusively to particular communities or to government agencies.

\section{B. Protection}

National laws and regional instruments are the primary sources of current protection for TK expressions. TK receives only limited protection under existing multinational treaties such as TRIPs. ${ }^{34}$ In countries with laws that specifically address TK, protection can come in two varieties: defensive and positive. Defensive TK protections ensure that TK rights to pre-existing TK content will not become restricted from use by

31 See Secretariat on the Convention on Biological Diversity, Sustaining Life on Earth: Convention on Biological Diversity (2000), $32 I d$. available at http://www.cbd.int/doc/publications/cbd-sustain-en.pdf.

33 See Genetic Resources, World InTEll. Prop. Org., http://www.wipo.int/tk/en/ genetic (last visited Dec. 5, 2010). See also Traditional Knowledge Digital Library, Council of Scientific \& Industrial Research (CSIR) \& Department of Ayurveda, Yoga \& Naturopathy, Unani, Siddha and HOMEOPATHY (AYUSH), http://www.tkdl.res.in/tkdl/langdefault/common/ Home.asp?GL=eng (last visited Dec. 5, 2010).

34 See infra Part II(A) (discussing the potential for protection of TK under classic copyright law, and therefore, under TRIPs). At the regional level, the African Regional Intellectual Property Organization and its member states recently adopted the Swakopmund Protocol on the Protection of Traditional Knowledge \& Expressions of Folklore (Aug. 9, 2010), available at http:// www.aripo.org/images/Swakopmund_Protocol.pdf. Other regional proposals have been floated for years. See, e.g., Paul Kuruk, Protecting Folklore Under Modern Intellectual Property Regimes: A Reappraisal of the Tensions Between Individual and Communal Rights in Africa and the United States, 48 Aм. U. L. REv. 769, 801 (1999) (advocating the "creation of a regional agency with authority to institute infringement actions abroad and to serve as the conduit for processing requests to use folklore as well as distributing compensation collected for the use of folklore."); see also supra note 2 (listing proposed regional initiatives dating back to the 1970s). 


\begin{tabular}{lllll}
\hline |ljciprod01 $\mid$ productn $\backslash \mathrm{C} \backslash \mathrm{CPY} \backslash 58-4 \backslash \mathrm{CPY} 404 . t x t$ & unknown & Seq: 13 & 31-OCT-11 & 11:23 \\
\hline
\end{tabular}

the original community. ${ }^{35}$ This protection is typically achieved by instituting a registry or database of existing TK, thus providing prior art which will defeat future claims of originality or novelty by those trying to assert copyright or patent rights over TK content. ${ }^{36}$ Certain defensive protections, such as database registration and authenticity markers, have been a long-standing part of the existing IPR structure. Although it is not always the case, defensive measures typically work to keep traditional knowledge in what would be the "public domain" in Western IP systems.

But there is an increasing movement towards positive TK protections as well. ${ }^{37}$ Positive TK protections grant exclusive rights over TK that are analogous to the rights granted by copyright law - rights that can be asserted to exclude, license, and profit from particular works. There are some common features among positive TK protections: (1) they require permission to use certain TK expressions, (2) they charge a license fee for this use, and (3) in many cases, the TK expressions are controlled and licensed by the state, and are restricted for "appropriate uses." A good example comes from Senegal's copyright law, where up to fifty percent of royalties generated from the sale of folklore-related items are funneled to the Bureau senegalais du droit d'auteur (Copyright office of Senegal). ${ }^{38}$ The remainder is retained by the person who collected the cultural expressions, or the person who modified them into a derivative work; ${ }^{39}$ the original community benefits only indirectly. ${ }^{40}$ The system in Senegal is not

35 Traditional Knowledge, World Intell. Prop. ORG., http://www.wipo.int/tk/ en/tk (last visited Dec. 5, 2010).

36 A number of countries have developed TK databases for documentary purposes, to defeat subsequent claims of novelty or originality. See Portal of Online Databases and Registries of Traditional Knowledge and Genetic Resources, World Intell. Prop. ORG., http://www.wipo.int/tk/en/databases/ tkportal (last visited Dec. 5, 2010).

37 Legislative Texts on the Protection of Traditional Cultural Expressions (Expressions of Folklore) (TCEs), World InTEll. Prop. Org., http://www.wipo. int/tk/en/laws/folklore.html (last visited Dec. 5, 2010) (citing countries with explicit protections for traditional cultural expressions ("TCE") through copyright provisions or through sui generis laws).

38 Senegal Copyright Act of 1973 (as amended in 1986) art. 9, available at http:// www.wipo.int/wipolex/en/text.jsp?file_id=179611. Other similar legislative schemes abound. Ghana, for example, vests complete ownership of folklore in the President of Ghana, and requires that users pay a fee to the National Folklore Board, as the board determines. The Board is then directed to use the funds to promote folklore and indigenous arts. Ghana Copyright Act of 2005, §§ 4, 17, 59-64.

39 Senegal Copyright Act of 1973 (as amended in 1986) art. 9, available at http:// www.wipo.int/wipolex/en/text.jsp?file_id=179611.

$40 \mathrm{Id}$. ("The proceeds from royalties shall be managed by the Bureau senegalais $d u$ droit d'auteur [BSDA] and used for cultural and welfare purposes for the benefit of authors."). 
unique; in just a quick survey of countries with explicit TCE protections, at least eighteen have systems in place for collection and receipt of fees to a central government agency. ${ }^{41}$ Of those eighteen, at least half require the governing authority to make some decision about the propriety of the suggested use. Some regimes go further and make usage distinctions based on whether the proposed user is a national or a foreigner of the country where the TK originated. ${ }^{42}$

In many cases, TK expressions are explicitly termed "public property," which is administered by the state. In Algeria, for example, works of "traditional cultural heritage" (explicitly termed "public property" in the act) are subject to control and licensure by the National Bureau of Copyright, which is directed to "control the extent of appropriate utilization" of TK expressions. ${ }^{43}$ Although foreign to users in the United States, this type of government control of the public domain is not a novel concept. Domaine public payant - prevalent in many developing countries - is a system which requires the payment of a fee to the government for the use of material in the public domain. ${ }^{44}$ The money is typically directed to be used for the support of indigenous arts and culture. ${ }^{45}$ This approach has been utilized in the past for works that have passed into the public domain, but it has generally been in the form of compulsory license. Protections applying to TK expressions can involve not only compulsory payment, but judgment on the part of the government agency as to the appropriateness of the use. This approach represents a fundamentally different and less solicitous view of the public domain than that found in the

41 See Legislative Texts on the Protection of Traditional Cultural Expressions (Expressions of Folklore) (TCEs), WORLd InTEll. Prop. Org., http://www. wipo.int/tk/en/laws/folklore.html (last visited Dec. 5, 2010) (citing countries with explicit protections for traditional cultural expressions ("TCE") through copyright provisions or through sui generis laws).

42 See, e.g., Indonesia Law No. 19 of July 29, 2002 on Copyright art. 10(2)-(3), available at http://www.wipo.int/wipolex/en/details.jsp?id=2262 (distinguishing between citizens of Indonesia and those who are not).

43 Algeria Droits d'auteur, Ordonnance arts. 139-142, 19/07/2003 - 1424, nº $03-$ 05.

44 See Carlos Mouchet, Problems of the "Domaine Public Payant", 8 Colum. J. L. \& ArTs 137, 137 (1983). In 1949, there were at least five countries employing this system. See United Nations Educ., Scientific \& Cultural Org., Domaine Public Payant (May 27, 1949) (UNESCO/DA/7), available at http://unesdoc.unesco.org/images/0014/001439/143960eb.pdf (listing Uruguay, Bolivia, Italy, Romania, and Yugoslavia with a domaine public payant system). By 1994 the number of countries with this system was over twenty. See Edwin R. Harvey, The Domaine Public Payant in Comparative Law with Special Reference to Argentina, Copyright Bull., Oct.-Dec., 1994, at 29.

45 See id. 


\begin{tabular}{lllll}
\hline |ljciprod01 $\mid$ productn $\backslash \mathrm{C} \backslash \mathrm{CPY} \backslash 58-4 \backslash \mathrm{CPY} 404 . t x t$ & unknown & Seq: 15 & 31-OCT-11 & 11:23 \\
\hline
\end{tabular}

legal tradition of Western countries, and especially that of recent scholarship from countries like the United States. ${ }^{46}$ Because many of these rights are enforced with little procedural recourse in courts, they may violate certain procedural protections found in TRIPs. Furthermore, if they are enforced discriminatorily against foreign users (as some seem to do), serious questions arise regarding the disruption of trade, especially where foreign users have already relied on the work's place in the public domain. ${ }^{47}$

\section{MOTIVATIONS FOR PROTECTION}

The real costs and benefits of traditional knowledge rights, in terms of intellectual freedom, preservation, and economic incentives, have been thoroughly debated. ${ }^{48}$ Generally speaking, TK protections are viewed by scholars and policy makers as providing important rights to indigenous peoples, who have in many cases been left out by the current international IPR system. ${ }^{49}$ Despite the general exuberance among international policy makers, TK protection does have its detractors. ${ }^{50}$ As one of the more outspoken skeptics, Professor Michael Brown described the support for TK protections as "reflexive expressions of solidarity," 51 and suggests a

46 See, e.g., James Boyle, The Public Domain: Enclosing the Commons of the Mind (2008); Lawrence Lessig, Free Culture: How Big Media Uses Technology and the Law to Lock Down Culture and Control Creativity (2004); Jessica Litman, The Public Domain, 39 Emory L.J. 965 (1990).

47 Removing items from the "public domain" may also raise other legal challenges - in the United States, First Amendment challenges - to enforcement at the international level. See, e.g., Golan v. Holder, 609 F.3d 1076, 1084 (10th Cir. 2010) (addressing challenges to the Uruguay Round Agreements Act which, in compliance with the Berne Convention, restored copyright for certain foreign works that had entered the public domain in the United States); see also Petition for Writ of Certiorari, Golan v. Holder, No. 10-545, available at http://blogs.law.stanford.edu/newsfeed/files/2010/10/ Golan-v.-Holder-Petition-for-Cert.pdf.

48 See Johanna Gibson, Community Resources: Intellectual Property, International Trade, and Protection of Traditional Knowledge (2005) (arguing for intellectual property rights that look beyond "efficient trade in information" and seek to protect and preserve communities); Stephen Munzer \& Kal Raustiala, The Uneasy Case for Traditional Knowledge, 27 Cardozo Arts \& Ent. L. J. 37 (2009); Kristen A. Carpenter, Sonia Katyal, \& Angela Riley, In Defense of Property, 118 YALE L.J. 1022 (2009).

49 See, e.g., Ragavan, supra note 15, at 4; Kuruk, supra note 34; see also Munzer \& Rastiala, supra note 48; Carpenter et al., supra note 48.

50 See, e.g., Michael F. Brown, Can Culture Be Copyrighted? 39 Current AnTHROPOLOGY 193 (1998) (arguing that TK protections are motivated by "romantic assumptions that ignore the broader crisis of intellectual property and the already imperiled status of the public domain").

51 Brown, supra note 50, at 219. 
careful study of the costs of such protection, acknowledging that stronger IP rights are not always a panacea to economic growth and capacity building. ${ }^{52}$ These criticisms have been met with the general response that TK protections cannot be framed in terms of only private property and access rights, without regard to the important relationship TK has with community trust, religion and obligations to relatives and ancestors. ${ }^{53}$ But for purposes of this article, a singular focus on property rights may be precisely the point; the United States in particular adheres to a system that emphasizes access rights (touching on free speech values), and private property (generally emphasized in U.S. IP policy). Community trust, religion, and ancestors are seldom emphasized in U.S. IP policy debates. ${ }^{54}$

In the United States, the basic goal of copyright protection is to incentivize the creation of new works by the grant of a time-limited monopoly over the particular expression. One famous articulation of this goal states:

The monopoly privileges that Congress may authorize are neither unlimited nor primarily designed to provide a special private benefit. Rather, the limited grant is a means by which an important public purpose may be achieved. It is intended to motivate the creative activity of authors and inventors by the provision of a special reward, and to allow the public access to the products of their genius after the limited period of exclusive control has expired. ${ }^{55}$

The U.S. system is unabashedly premised on the utilitarian goal of increasing the production of and access to knowledge, and thereby increasing overall well-being. ${ }^{56}$ While other countries in the global North have copy-

52 Even the empirical support for traditional IPRs in developing countries is mixed, and has been for some time. See, e.g., Robert L. Ostergard, Jr., The Development Dilemma 59 (2003) ("Earlier studies have suggested that IPRs have a positive effect in a number of ways promoting economic growth and that these benefits are universal in nature. ... Using a different measure of IPR protection, no consistent evidence emerged to show that IPRs contributed significantly to economic growth cross-nationally. . . . More important are the negative coefficients attached to many IPR variables, [which imply] that states may see negligible effects and quite possible negative effects from adopting strong IPR protection.").

53 See Kuruk, supra note 34, at 825; Rosemary J. Coombe, Michael F. Brown's Can Culture Be Copyrighted?, 39 Current Anthropology 207, 207-08 (1998) (commentary).

54 See Anupam Chander \& Madhavi Sunder, The Romance of the Public Domain, 92 CAL. L. REv. 1331, 1332-33 (2004) (describing the law and economics, Chicago-school "crusade" to propertize the intellectual commons).

55 Sony Corp. of Am. v. Universal City Studios, Inc., 464 U.S. 417, 429 (1984).

56 Note that in some circumstances copyright law has been held to "also serve[ ] authors' First Amendment interests. '[F]reedom of thought and expression 'includes both the right to speak freely and the right to refrain from speaking at all.'" Golan v. Holder, 609 F.3d 1076, 1084 (10th Cir. 2010) (quoting Harper \& Row, Publishers, Inc. v. Nation Enters., 471 U.S. 539, 559 (1985)). 


\begin{tabular}{lllll}
\hline |ljciprod01 $\mid$ productn $\backslash \mathrm{C} \backslash \mathrm{CPY} \backslash 58-4 \backslash \mathrm{CPY} 404 . t x t$ & unknown & Seq: 17 & 31-OCT-11 & 11:23 \\
\hline
\end{tabular}

right systems that take a less fundamentally utilitarian position and afford more protection for things like "moral rights," initial eligibility for copyright still hinges on a concept of original authorship or new creation. ${ }^{57}$

The important qualifying attributes for the protection of traditional cultural expressions are very different from the types of qualifying attributes under U.S. and European copyright regimes. Perhaps because they are lobbied for and created by a diverse set of participants, TK protections have a less unified theoretical backing. TK protections allow for community-based ownership of resources based on a concern for equity in intellectual property and economic development, concerns over the legitimization of indigenous IP, and a number of other practical concerns. The sections below outline how TK expressions align with those of "classic" copyright as found in the United States or the European Community, and how protections of TK expressions are justified in the literature and in national legislation.

\section{Motivations for Classic Copyright Protection}

Original authorship has been described as the sine qua non of U.S. copyright protection. ${ }^{58}$ Duke Law professor James Boyle gives a critical but accurate - description of "authorship" in the Western realm:

The author concept stands as a gate through which one must pass in order to acquire intellectual property rights. At the moment, this is a gate that tends disproportionately to favor the developed countries' contributions to world science and culture. Curare, batik, myths, and the dance "lambada" flow out of developing countries, unprotected by intellectual property rights, while Prozac, Levis, Grisham, and the movie Lambada! flow in - protected by a suite of intellectual property laws, which in turn are backed by the threat of trade sanctions. ${ }^{59}$

In the United States, authorship is bounded by the requirement of a "modicum of creativity" in the creation - an idea that implicates both "original creation" on the part of the author, and a certain amount of creativity. ${ }^{60}$ Thus, copyright law does not provide protection for items that are copied wholesale from preexisting works, or for items that are not "creative" works. Further, to achieve copyright protection, the expression must be fixed in a tangible medium that is communicable to others. ${ }^{61}$

57 See, e.g., Code de la propriété intellectuelle [C. Prop. Int.] art. L112-1 (Fr.) (droits des auteurs ("author's rights")); Urheberrechtsgesetz [UrhG] [Copyright Law], Sep. 9, 1965, as amended, arts. 13-14 (Ger.) (author's rights).

58 Feist Publ'ns, Inc. v. Rural Tel. Serv. Co., 499 U.S. 340, 345 (1991).

59 James Boyle, Shamans, Software, and Spleens: Law and the ConSTRUCTION OF THE InFORMATION SOCIETy 125 (1996).

60 Feist, 499 U.S. at 346.

61 See 17 U.S.C. $\$ 102$ (2006). Note that the Berne Convention does not necessarily require fixation. See supra note 26. 
\begin{tabular}{lllll}
\hline |ljciprod01 $\mid$ productn $\backslash \mathrm{C} \backslash \mathrm{CPY} \backslash 58-4 \backslash \mathrm{CPY} 404 . t x t$ & unknown & Seq: 18 & 31-OCT-11 & 11:23 \\
\hline
\end{tabular}

It is generally well recognized that many TK protections fall outside the scope of classic copyright protection, in large part because TK expressions are oftentimes not attributable to a particular author or even an identifiable group of authors. ${ }^{62}$ In some cases, such as with contemporary tradition-based works, the requirement of showing an identifiable author is simple. ${ }^{63}$ But in situations involving TK expressions that have been in existence for many generations, or TK that have developed over time with many contributors, identifying an author is impossible. For the same reasons, traditional cultural expressions cannot be works of "joint authorship" any more than they can be original works of individual authorship. This is so because joint authorship still requires an identifiable group of contributors, who (at least in the United States) intend for their creative contributions to merge into one work. ${ }^{64}$ Joint authorship merely requires more authors, but no less authorship.

The inability to identify a particular author or group to award rights to for TK expressions represents a basic incompatibility with the motivations of copyright protection. As noted above, copyright in the United States is premised on the idea that the monopoly right can be used as an economic incentive for the creation of new works. With TK expressions however, there is no identifiable group or individual to incentivize. Creation of the work would likely occur without the monopoly privileges, and in fact, the generations-old nature of TK expressions indicates that that is indeed the case. Perhaps a stronger argument could be made for TK expressions under a natural rights rationale. But even then, with no identifiable creators, rights would not be awarded as fruits of the community's labor in creating the work, but rather, for the community's role as custodian of the work.

In a similar vein, many TK expressions are not copyrightable because they lack sufficient originality. ${ }^{65}$ Although originality is not a defined term in either the Berne convention of TRIPs, it is clear from Articles 2.1 and 2.5 of the Berne Convention that works protected by copyright must be "intellectual creations." 66 As noted above, this is borne out in U.S. law through the requirement that protectable works of authorship have at

62 See World Intell. Prop. Org., Consolidated Analysis of the Legal Protection of Traditional Cultural Expressions/Expressions of Folklore, Background PAper No. 1, at 35 (2003) [hereinafter ConsoliDATED ANALYSIS].

63 Id. at 38.

64 See 17 U.S.C. $\$ 101$ (2006) (“A ‘joint work’ is a work prepared by two or more authors with the intention that their contributions be merged into inseparable or interdependent parts of a unitary whole.").

65 See Consolidated Analysis, supra note 62, at 38.

66 Berne Convention art. 2. 


\begin{tabular}{lllll}
\hline |ljciprod01 $\mid$ productn $\backslash \mathrm{C} \backslash \mathrm{CPY} \backslash 58-4 \backslash \mathrm{CPY} 404 . t x t$ & unknown & Seq: 19 & 31-OCT-11 & 11:23 \\
\hline
\end{tabular}

least some modicum of originality. ${ }^{67}$ Because many TK expressions are merely copies of preexisting works, they do not meet the originality requirement of copyright. Protection may be available for authors who later modify preexisting TK expressions into derivative or transformative works, and those types of activities are quite in line with the traditional motivations of copyright law. This is so because both the identifiable author requirement and the originality requirement support the creation of new content. TK expressions may also fail other technical requirements for copyright protection (for example, the fixation requirement), but the basic tension between TK protections on the one hand, and copyright on the other, is that copyright promotes the creation of entirely new, or at least transformative, work, while TK protections, as discussed below, promote the maintenance of preexisting content.

\section{Motivations for TK Protection}

The following section provides a summary of a few of the major points that have been offered in support of protection of TK expressions. While these in no way represent the whole of all rationales supporting TK protections, they are representative of the types of arguments being made. The motivations outlined below are those of equity in intellectual property ownership and economic development, legitimization of TK in the world of global trade, and finally, the preservation of TK expressions.

\section{Equity in Intellectual Property Ownership and Economic Development}

Copyright law, and IPRs in general, favor the creation of the new works, while TK protections do not. Rather than pointing to information flows (i.e., the amount of new content created), proponents of protections of TK expressions instead point to information stocks (i.e., the current amount of intellectual property existing under protective schemes). Under this rubric, those proponents are right that the stock of indigenous knowledge is underrepresented and undervalued in the global economy. The value of tradition has largely been ignored by copyright protections that promote only creativity and innovation. As one commentator notes, "[i]t is critical that attention remains on the value that is at stake, not the value that is to be created." 68 Yet TK protections seek to rectify this basic inequality, challenging the presumption that, as one TK advocate states, "[t]he intellectual products held in the developing world rest in a global

67 Feist Publ'ns, Inc. v. Rural Tel. Serv. Co., 499 U.S. 340, 345 (1991).

68 Johanna Gibson, Knowledge and Other Values - Intellectual Property and the Limitations of Traditional Knowledge, in EMERGING IsSUES IN INTELLECtual Property 309, 318 (Guido Westkamp ed., 2007). 


\begin{tabular}{lllll}
\hline |ljciprod01 $\mid$ productn $\backslash \mathrm{C} \backslash \mathrm{CPY} \backslash 58-4 \backslash \mathrm{CPY} 404 . t x t$ & unknown & Seq: 20 & 31-OCT-11 & 11:23 \\
\hline
\end{tabular}

public domain, while the intellectual products of the developed world are held closely by corporations." 69

\section{Legitimization}

Another justification offered for traditional knowledge protections is the legitimization of traditional knowledge as a valuable resource..$^{70}$ This line of reasoning asserts that "cultures are recognized and authorised, and rendered legitimate information for trade according to the model presented by a Western intellectual property imperative." ${ }^{1}$ There is certainly truth to this statement. From the vantage point of the Western world, it is remarkable to see the mobility of works protected by IPRs in all sorts of cultures; visiting a mall in Germany, one can hear Michael Jackson and Britney Spears over the loud speakers; others may find sparkling white Nike sneakers while shopping at a market in Guinea. ${ }^{72}$ Intellectual property rights certainly foster the distribution, if not the creation, of these cultural items. Without these rights, the costs required to create and distribute those items would be impossible to recoup. But these economic realities are changing, especially in the Global North - the transaction costs associated with creation, distribution, and adaptation are decreasing in dramatic ways, and cultural items may no longer be seen as deriving their value or worth merely from economic protections. So, although legitimization as a means to economic viability may still have some resonance with Western policy makers, legitimization for knowledge as an end in itself may fall on deaf ears. ${ }^{73}$

\section{Preservation}

The call to use TK protection as a means to "preserve" certain elements of culture is simultaneously one of the strongest arguments both for and against the internationalization of TK protections. Preservation in the context of positive TK protections essentially means "control," as many of

69 Chander \& Sunder, supra note 54, at 1353.

70 Gibson, supra note 68, at 310-11 ("Knowledge is without value until it is recognised and transferred within intellectual property frameworks. ... An understanding of the legitimation and institutionalisation of the intellectual property narrative provides a critical insight into the fundamental conflicts generated by the assimilation of traditional knowledge within intellectual property laws ....”).

71 Id. at 312 .

72 These examples are based on recent trips abroad.

73 Gibson, supra note 68, at 310 (arguing for "[t]his kind of incremental change through the communication of knowledge as an end, rather than the exchange of knowledge in order to manifest value and creatorship, is what has been argued to be unregistered within intellectual property regimes."). 


\begin{tabular}{lllll}
\hline |ljciprod01 $\mid$ productn $\backslash \mathrm{C} \backslash \mathrm{CPY} \backslash 58-4 \backslash \mathrm{CPY} 404 . t x t$ & unknown & Seq: 21 & 31-OCT-11 & 11:23 \\
\hline
\end{tabular}

the calls for preservation are based on concerns over dilutive copying. ${ }^{74}$ For example, the IGC draft international instrument for TCE protection contains the following section on "misappropriation and misuse":

$[\mathrm{T}]$ here shall be adequate and effective legal and practical measures to ensure that the [relevant community] . . . can prevent or stop the following acts taking place...

(i) the reproduction ... of the traditional cultural expressions/expressions of folklore or [derivative works or adaptations] thereof;

(ii) any use of the traditional cultural expressions/expressions of folklore or adaptation thereof which does not acknowledge in an appropriate way the [community] indigenous peoples and communities ... as the source or owner of the traditional cultural expressions/expressions of folklore . . (iii) any distortion, mutilation or other modification ... that may be prejudicial to the expressions, that would offend against or would damage the reputation ... or image of the community, indigenous peoples and communities or region or nation to which they belong. ${ }^{75}$

Protections like these fall somewhat in line with the droits d'auteur natural-rights rationale for copyright protection. ${ }^{76}$ But even then, protection is premised on the romantic notion of an independent (and identifiable) creator. Protections like those granted in the IGC draft will go a step further, awarding retrospective moral rights to claimants based on their geographic location, ancestry, or some other removed relation to the work. ${ }^{77}$ Essentially, rights are awarded based on a theory of custodianship or lineage rather than creative contribution to the work itself. Given the expansive control that some of these protections would grant, one might

74 Protection of Traditional Cultural Expressions, supra note 16, art. 3, annex, at 29.

75 Id.

76 See Wendy J. Gordon, A Property Right in Self-Expression: Equality and Individualism in the Natural Law of Intellectual Property, 102 YALE L.J. 1533, 1549, 1552 (1993) (explaining Lockean rationales for authors' rights).

77 See Kuruk, supra note 34, at 804 ("Despite descriptions of the term 'folklore,' the statutory references in African legislation suffer from certain definitional deficiencies. One problem concerns the absence of criteria for determining the size of the social group relevant to the formation of a work of folklore. For example, in addition to the practices of tribal groups, would folklore also encompass practices found amongst lineages, the smaller social groups of tribes? When does a work fail to qualify as folklore because the creating group is too small?"); see also World Intell. Prop. Org., Intergovernmental Committee on Intell. Prop. and Genetic Resources, Traditional Knowledge and Folklore, The Protection of Traditional Cultural Expressions/Expressions of Folklore: Factual Extraction 57 (12th Session Geneva, Jan. 31, 2008) (WIPO/GRTKF/IC/ 12/4(b)), available at http://www.wipo.int/edocs/mdocs/tk/en/wipo_grtkf_ic_ 12/wipo_grtkf_ic_12_4_b.pdf (debating "how should beneficiaries and rights holders be identified? How should the "link" between a TCE and a beneficiary/right holder be construed and determined?"). 
expect an extensive qualification procedure for those groups seeking to assert TK rights, but those qualification procedures (where they exist) are still vague on many points. ${ }^{78}$

In many countries, TK rights are currently being administered by a "competent government authority," thus removing the need to clearly identify particular communities or groups to hold the TK rights. ${ }^{79}$ But those authorities must then play some gatekeeping role with respect to positive TK expressive rights. So, it appears to U.S and European policy makers that developing nation governments are put in the uncomfortable position of deciding who can and cannot use particular expressions. In these situations, it is not merely governments making "content-neutral" decisions regarding which groups of people are granted protection, as would be the case under true domaine public payant systems. Rather, it requires governments to decide which particular uses of particular expressions would be "harmful," "prejudicial," or "offensive" to the community or nation from whence they came. This is precisely the point of preservation via control. Societies have, for ages, constructed sumptuary laws to preserve these consumption practices. ${ }^{80}$ As Professor Barton Beebe notes, "TCEs protection represents the most ambitious - and reactionary - form of sumptuary intellectual property law that we have." 81 Even without addressing in detail the legal issues associated with enforcement in Western countries, it is easy to suggest that restrictions of this nature are bound to generate friction in Western realms where there is a high level of resistance to government regulation of access to information (and by extension free speech) .82

Another objection to this form of preservation via "control" is that it may actually be harmful to the continued vitality and relevance of TK expressions. As the European Community warns in response to the IGC on the protection of folklore, "[i]f expressions of folklore were fully pro-

78 Id

79 See supra notes 38-47 and accompanying text.

80 See Barton Beebe, Intellectual Property \& the Sumptuary Code, 123 Harv. L. REV. 809, 812 (2010) ("A society's sumptuary code is its system of consumption practices, akin to a language (or at least "a set of dialects"), by which individuals in the society signal through their consumption their differences from and similarities to others. Laws that seek to control and preserve this code are sumptuary laws.").

81 Id. at 875 .

82 In the United States, the mere reinstatement of copyright over certain foreign works has been contentions - although courts have generally concluded that such activity is "content neutral" for First Amendment purposes. See, e.g., Eldred v. Ashcroft, 537 U.S. 186 (2003); Golan v. Holder, 609 F.3d 1076, 1084 (10th Cir. 2010). It would be difficult to imagine, however, a U.S. Court willing to enforce restrictions on TK knowledge that are not only retroactive, but also blatantly content specific. 


\begin{tabular}{lllll}
\hline |ljciprod01 $\mid$ productn $\backslash \mathrm{C} \backslash \mathrm{CPY} \backslash 58-4 \backslash \mathrm{CPY} 404 . t x t$ & unknown & Seq: 23 & 31-OCT-11 & 11:23 \\
\hline
\end{tabular}

tected, this could almost have the effect of casting it in concrete," 83 preventing further innovation. The point is that it is possible to preserve one's self into irrelevance. An example from my own life - one of my father's favorite shows when he was younger was the show The Six Million Dollar Man. It is a show from the 1970's about an astronaut, Steve Austin, whose ship crashed, leaving him nearly dead. A group of scientists were able to rebuild him - giving him superhuman strength and speed. I know all about the show - the characters, the theme song, the shows. The tag line went like this: "We can rebuild him. We have the technology. . . . Better than he was before. Better, stronger, faster." 84 Because we would talk about it all the time, I watched the show growing up, getting episodes through peer-to-peer networks, and later, YouTube. I have seen almost all of the episodes; the show has become part of our "culture."

But I was born in 1986, well after The Six Million Dollar Man aired on ABC. ${ }^{85}$ The show has never been released on DVD. ${ }^{86}$ Yet I was able to experience this "cultural expression" with little or no difficulty. ${ }^{87}$ Some might question whether it was because of, or in spite of, strong copyright protection that I was able to see this show. Of course, preservation of ancient spiritual rituals may deserve considerably more respect than The Six Million Dollar Man. However, the same objections and questions arise: Is close management of TK expressions really more beneficial to the works themselves? Will applying restrictive rights to TK expressions make them irrelevant to the outside world? Is that desirable? Who will ensure that these works continue to be preserved? Who will have access to them?

\section{E. Whose Public Domain?}

Just as the term "preservation" is subject to multiple interpretations, the " "public domain' is also a protean concept." 88 At its most basic, the public domain is a space filled with content unprotected by intellectual

83 Intergovernmental Committee on Intell. Prop. And Genetic Resources, Traditional Knowledge and Folklore, Expressions of Folklore, Third Session Geneva, June 13 to 21, 2002, at 1 (document submitted by the European Community and its Member States).

84 The Six Million Dollar Man, Internet Movie Database, http://www.imdb. com/title/tt0071054 (last visited Dec. 5, 2010).

85 The TV Guide TV Book: 40 Years of the All-Time Greatest Television Facts, Fads, Hits, And History 174 (Ed Weiner ed., 1992).

86 The complete series is slated for release on November 23, 2010 for $\$ 239.95$. See The Six Million Dollar Man DVD Set, Time Life (2010), http://6mdm. com.

87 Note that downloading these works was likely in violation of U.S. copyright law. This article does not argue that Western IPRs do not share some of the same objections regarding control over intellectual works.

88 Chander \& Sunder, supra note 54, at 1337. 
\begin{tabular}{lllll}
\hline |ljciprod01 $\mid$ productn $\backslash \mathrm{C} \backslash \mathrm{CPY} \backslash 58-4 \backslash \mathrm{CPY} 404 . t x t$ & unknown & Seq: 24 & 31-OCT-11 & 11:23 \\
\hline
\end{tabular}

property rights. In the United States, the debate has narrowed in on both the outer bounds of the public domain and the process by which materials become deposited in it.89 At one end of the spectrum is the "crumbs" theory, where creative work is deposited into the public domain after intellectual property rights have used up some of its usefulness. ${ }^{90}$ At the other end of the spectrum is a free and open public domain of resources that are deposited there intentionally, and which are shared among all people. ${ }^{91}$ Somewhere in the middle is a conception of the public domain as a potential default rule; "the common space where creative works not protected by copyright exist. Public domain should be the default condition for creative works. . . I If public domain is the norm, then copyright protection should be afforded only when certain conditions are met." 92

The discussion of the "public domain" in the context of protections of TK expressions has also received attention, although its bounds are much less defined. In a recent, fairly comprehensive report on the relationship of TK protections to the public domain, the IGC recognizes that " $[\mathrm{t}]$ he public domain is, however, an elastic, versatile and relative concept and it is not susceptible to a uniform legal meaning. Its meaning and effect in IP theory are not yet well understood. The term rarely appears in legal texts and it is even rarer that specific rules are attached to it." 93 The report goes on the state that in the view of many TK proponents, there must be a number of different public domains with overlapping "knowledge-sharing

89 Id.

90 See Chander \& Sunder, supra note 54, at 1337; see also David Lange, Reimagining the Public Domain, 66 Law \& Contemp. Probs. 463, 465 (2003) (describing the public domain as what is left over after intellectual property rights); Laura N. Gasaway, A Defense of the Public Domain: A Scholarly Essay, 101 LAw LiBRARY J. 451, 457 (2009) (explaining the phrase "fell into the public domain" as degrading to the concept of the public domain).

91 See generally James Boyle, The Second Enclosure Movement and the Construction of the Public Domain, 66 Law \& Contemp. Probs. 33 (2003).

92 Gasaway, supra note 90, at 452.

93 World Intell. Prop. Org., Intergovernmental Committee on Genetic Resources, Traditional Knowledge and Folklore, Note on the Meanings of the Term "Public Domain" in the Intellectual Property System with Special Reference to the Protection of Traditional Knowledge and Traditional Cultural Expressions/ ExPressions of Folklore 2 (17th Session, Geneva, Nov. 24, 2010) (WIPO/GRTKF/IC/17/INF/8), available at http://www.wipo.int/edocs/ mdocs/tk/en/wipo_grtkf_ic_17/wipo_grtkf_ic_17_inf_8.pdf [hereinafter Notes on the Meanings of the Public Domain]. 


\begin{tabular}{lllll}
\hline |ljciprod01 $\mid$ productn $\backslash \mathrm{C} \backslash \mathrm{CPY} \backslash 58-4 \backslash \mathrm{CPY} 404 . t x t$ & unknown & Seq: 25 & 31-OCT-11 & 11:23 \\
\hline
\end{tabular}

spaces." 94 Towards this end, a "Traditional Knowledge Commons" has been proposed. ${ }^{95}$

In existing national TK protection laws, TK expressions are oftentimes simultaneously considered part of the "public domain" and yet subject to regulation by the relevant governing state. This makes sense as "many stakeholders have emphasized that [TCEs] are generally regarded as collectively originated and held, so that any rights and interests in this material should vest in communities rather than individuals."96 In addition to grants of rights to the state-through domaine public payant systems, for example - grants to particular communities are also common. This is almost universally recognized as conflicting with traditionally Western - and in particular, U.S. - conceptions of the public domain. ${ }^{97}$

The domaine public payant system has existed for decades and is well recognized; even if it conflicts with Western conceptions of the public domain, it might be afforded historical respect. Even Lawrence Lessig seems to concede that a knowledge commons might include works that must be paid for, so long as the payment is non-discriminatory and is structured as a liability rule..$^{98}$ But the domaine public payant as applied to TK takes on a new dimension. Rather than working as a compulsory license to fund arts and culture, TK protections are mediated by the state as a property rule, where governments are deciding not only appropriate fees to charge, but appropriate uses for the TK expressions. The African country of Burkina Faso, for example, takes this approach. It requires that any commercial publication, reproduction, distribution, or public performance be

94 Id.

95 See Int'l Development Law Org., Imagining a Traditional KnowlEDGE COMMONs (2009), available at http://www.naturaljustice.org/images/ naturaljustice/tk\%20commons\%20book-final.pdf.

96 Protection of Traditional Cultural Expressions, supra note 16, art. 2, annex, at 21.

97 See generally Notes on the Meanings of the Public Domain, supra note 93.

98 Lawrence Lessig, The Future Of Ideas: The Fate of the Commons in a Networked World 20 (2001) (noting that the commons may be "free even though a price must be paid (a park is 'free' in the sense that I mean even if an access fee is required-so long as the access fee is neutrally and consistently applied)."). The term "liability rule" as used here is commonly understood to mean the situation where the law provides for a legally protectable entitlement but the right is not inalienable. When one violates the entitlement, the holder is merely awarded an objectively determined amount. This is contrasted with a "property rule" where the holder is entitled to exclude and where the award may be injunctive rather than monetary. See generally Guido Calabresi \& A. Douglas Melamed, Property Rules, Liability Rules, and Inalienability: One View of the Cathedral, 85 Harv. L. Rev. 1089 (1972). 


\begin{tabular}{lllll}
\hline |ljciprod01 $\mid$ productn $\backslash \mathrm{C} \backslash \mathrm{CPY} \backslash 58-4 \backslash \mathrm{CPY} 404 . t x t$ & unknown & Seq: 26 & 31-OCT-11 & 11:23 \\
\hline
\end{tabular}

licensed from the Burkina Faso Collective Management Organization in cooperation with its Minister of Culture. ${ }^{99}$ No license is required for the creation of derivative works made by the people of Burkina Faso, but derivative works created by foreigners are first subject to approval by the Collective Management Organization. ${ }^{100}$ As noted above, there may be many public domains and many theories of the public domain, but TK protections that distinguish between those users inside the country and those who are foreigners very clearly answer the question "whose public domain?"101

\section{WORKING WITHIN THE WTO}

The World Trade Organization ("WTO") was created in 1995 as the culmination of the Uruguay Round negotiations, which created a new set of rules that covered almost every aspect of international trade policy, including intellectual property. ${ }^{102}$ The WTO plays three important roles in facilitating trade: (1) it provides a forum for negotiation for countries to settle trade disputes, (2) it provides a set of base rules for international commerce, and (3) it provides a Dispute Settlement Body - and then an Appellate Body in failed dispute settlements - which interprets the legal requirements of the WTO trade agreements. ${ }^{103}$ At least two WTO agreements may be applicable to traditional knowledge protections: the General Agreement on Tariffs and Trade ("GATT"), and the Agreement on Trade Related Aspects of International Property Rights ("TRIPs").

99 See Burkina Faso Law No. 032-99/AN on the Protection of Literary and Artistic Property art. 91.

100 Id. art. 92.

101 Another example is Indonesia, whose copyright law states that "[t]he State shall hold the Copyright for folklores and works of popular culture that are commonly owned, such as stories, legends, folk tales, epics, songs, handicrafts, choreography, dances, calligraphies and other artistic works," and that " $[\mathrm{t}] \mathrm{o}$ publish or reproduce the works as referred to in [the previous sentence], any person who is not the citizen of Indonesia shall, firstly, seek permission from the institution related to the matter." Indonesia Law No. 19 of July 29, 2002 on Copyright art. 10(2)-(3), available at http://www. wipo.int/wipolex/en/details.jsp?id=2262.

102 World Trade Org., Understanding the WTO 18 (5th ed. 2010), available at http://www.wto.org/english/thewto_e/whatis_e/tif_e/understanding_e.pdf.

103 See id. at 55-58; see also Hwan Kim, The World Trade Organization Dispute Settlement System: China - Measures Affecting the Protection and Enforcement of Intellectual Property Rights, 23 N.Y. INT'L L. REv. 83, 96 (2010); cf. The WTO As An International Organization 46 (Anne O'Krueger \& Chonira Aturupane eds., 1998). 


\begin{tabular}{lllll}
\hline |ljciprod01 $\mid$ productn $\backslash \mathrm{C} \backslash \mathrm{CPY} \backslash 58-4 \backslash \mathrm{CPY} 404 . t x t$ & unknown & Seq: 27 & 31-OCT-11 & 11:23 \\
\hline
\end{tabular}

\section{F. The GATT "Filter" of Prohibiting Disguised Restrictions on Trade}

In the language of GATT, IPRs are treated as an exception, rather than a compliment, to the general rule of free trade. GATT Article XX(d) provides:

Subject to the requirement that such measures are not applied in a manner which would constitute a means of arbitrary or unjustifiable discrimination between countries where the same conditions prevail, or a disguised restriction on international trade, nothing in this Agreement shall be construed to prevent the adoption or enforcement by any contracting party of measures ... (d) ... the protection of patents, trademarks and copyrights, and the prevention of deceptive practices. ${ }^{104}$

Under GATT, countries are free to protect patents, trademarks, and copyrights specifically, although the words themselves are not defined. Positive TK protection of expressions does not fall neatly within the express exceptions of "patents, trademarks, and copyrights," and so the very existence of positive TK protections immediately casts doubt on whether they are permissible under GATT. ${ }^{105}$ In cases where TK protections are entirely sui generis, they may not be considered part of the protection of "patents, trademarks, and copyrights, and the prevention of deceptive practices." But in many national legislative schemes positive TK protections are included as part of the national copyright scheme. ${ }^{106}$ Thus, it is arguable that TK protections of expressions fall within the bounds of "copyright" for purposes of the GATT Article XX exception. ${ }^{107}$

The WTO has interpreted GATT Article XX as a provision which allows for the balancing of rights and obligations of WTO members. ${ }^{108}$ Towards that end, it has taken a broad interpretation of the "disguised restrictions on trade" provision. The WTO Appellate Body has stated that "[w]e consider that 'disguised restriction,' whatever else it covers, may properly be read as embracing restrictions amounting to arbitrary or unjustifiable discrimination in international trade taken under the guise of a measure formally within the terms of an exception listed in Article

$\overline{104 \text { GATT }}$ art. 20.

105 This provision alone may be enough to object to TK protections as restrictions on the trade of goods, outside the Article 20 exceptions, and therefore subject to the substantive rules of GATT.

106 See Part I(B) (protection of TK).

107 TK protections of expressions may not, however, fall within the bounds of "copyright" for purposes of TRIPs because TRIPs borrows a very narrow definition of copyright taken from the Berne Convention. See infra notes $137-145$.

108 United States - Import Prohibition of Certain Shrimp and Shrimp Products, Report of the Appellate Body, AB-1998-4, II 159 (Oct. 12, 1998) (WT/ $\mathrm{DS} 58 / \mathrm{AB} / \mathrm{R})$. 
XX."109 The Appellate Body also held that for national measures to fit within the exceptions of GATT Article XX(d), "[f]irst, the measure must be designed to 'secure compliance' with laws and regulations that are not themselves inconsistent with some provisions of the GATT 1994. Second, the measure must be 'necessary' to secure such compliance."110

Thus, GATT Article XX serves as filtering mechanism for TK protections, because some analysis must first be conducted as to whether the existence of the laws themselves are inconsistent with some provision of GATT 1994. As shown below in the TRIPs analysis, this may very well be the case (however, a country-by-country analysis would ultimately be necessary). Moreover, GATT Article XX requires that these provisions be "necessary" to secure compliance with those laws. ${ }^{111}$ Because the bounds of "necessary" are further borne out in the specific procedural rules of TRIPs, it is those provisions that will be examined.

\section{G. TRIPs as a Maximum-Rights Treaty}

At first glance, it may seem odd to speak about TRIPs as a free-trade instrument. A cynic views the creation of TRIPs as the ironic result of "Washington and Brussels bureaucrats participat[ing] in a trade think speak' in which global monopoly privileges are entirely consistent with free trade." 112 And yet TRIPs does accomplish something important for free trade: it establishes minimum uniform intellectual property rights. The benefits are obvious-imagine, in the world of personal property, if an individual had to worry every time he traveled overseas whether his suitcase would somehow become part of the "public domain." Uniform rules in the realm of intellectual property are thought to alleviate similar fears, and thereby facilitate trade. Of course, those uniform rules can become a burden on trade itself, as the text of TRIPs itself recognizes.

TRIPs is typically thought of as a minimum standards treaty, meaning that members are free to provide protections above what its provisions require. Indeed, TRIPs Article 1.1 explicitly states that " $[\mathrm{m}]$ embers may, but shall not be obliged to, implement in their law more extensive protec-

109 United States - Standards for Reformulated and Conventional Gasoline, AB1996-1, at 25 (Apr. 26, 1996) (WT/DS2/AB/R).

110 Korea - Various Measures on Beef, Report of the Appellate Body II157 (Dec. 11, 2000) (WT/DS161/AB/R \& WT/DS169/AB/R).

111 "Necessary" in this context has been interpreted as follows: "At one end of this continuum lies 'necessary' understood as 'indispensable'; at the other end, is 'necessary' taken to mean as 'making a contribution to.' We consider that a 'necessary' measure is, in this continuum, located significantly closer to the pole of 'indispensable' than to the opposite pole of simply "making a contribution to." Id. II 161.

112 Peter Drahos \& John Braithwhite, Information Feudalism 37 (2002). 


\begin{tabular}{lllll}
\hline |ljciprod01 $\mid$ productn $\backslash \mathrm{C} \backslash \mathrm{CPY} \backslash 58-4 \backslash \mathrm{CPY} 404 . t x t$ & unknown & Seq: 29 & 31-OCT-11 & 11:23 \\
\hline
\end{tabular}

tion than is required by this Agreement."113 However, Article 1 goes on to provide a specific limitation on additional substantive protections, only allowing more extensive measures "provided that such protection does not contravene the provisions of this Agreement." 114 Although TRIPs is, for the most part, a minimum-rights treaty, it does contain a number of "maximums" that are specifically designed to reign in the scope and enforcement of IPRs. ${ }^{115}$ In fact, these limitations are present throughout: in the Preamble, ${ }^{116}$ Article 3 (national treatment), ${ }^{117}$ Article 7 (objectives), ${ }^{118}$ Article 41 (procedural minimums for enforcement), ${ }^{119}$ and Article 42 (fair and equitable procedures for rights holders). ${ }^{120}$ The WTO delegate from India, addressing border seizures in the European Union stemming from

113 TRIPs Agreement art. 1(1).

114 Id.

115 Denis Borges Barbosa, Minimum Standards vs. Harmonization in the TRIPS Context: The Nature of Obligations Under TRIPS and Modes of Implementation at the National Level in Monist and Dualist Systems, in RESEARCH Handbook on the Protection of Intellectual Property Under WTO Rules 52, 73 (Carlos María Correa, ed., 2010) (quoting a version of Josef Drexl's article, The TRIPS Agreement and the EC: What Comes Next After Joint Competence?"). Drexl notes:

Nevertheless, existing TRIPs standards may conflict with TRIPs-plus standards in bilateral agreements in cases in which the former do not only define minimum, but also maximum standards. Although it seems, according to Art. 1.1 TRIPs, that such maximum standards are inherently foreign to the concept of the TRIPs, the Agreement nevertheless prohibits "more intensive protection" in its provisions on enforcement of Part III to the extent that it fixes general procedural provisions to the benefit of any party to IP litigation. In some instances, the Agreement even explicitly provides for procedural rights of the defendant, like with regard to the level of legal certainty as a requirement for provisional measures (Art. 50.3 TRIPs) and the rights of the alleged infringer to be informed and to be heard within a reasonable time after provisional measures have been adopted inaudita altera parte (Art. 50.4 TRIPs). Most strikingly, art. 48 TRIPs provides for a right to indemnification of the defendant in case of an abuse of enforcement procedures.

116 TRIPs Agreement preamb. ("[T]o ensure that measures and procedures to enforce intellectual property rights do not themselves become barriers to legitimate trade.").

117 Id. art. 2 ("Each Member shall accord to the nationals of other Members treatment no less favourable than that it accords to its own nationals with regard to the protection of intellectual property.").

118 Id. art. 7 (committing to "to a balance of rights and obligations").

119 Id. art. 41 ("These procedures shall be applied in such a manner as to avoid the creation of barriers to legitimate trade and to provide for safeguards against their abuse.").

120 Id. ("Members shall make available to right holders civil judicial procedures concerning the enforcement of any intellectual property right covered by this Agreement."). 


\begin{tabular}{lllll}
\hline |ljciprod01 $\mid$ productn $\backslash \mathrm{C} \backslash \mathrm{CPY} \backslash 58-4 \backslash \mathrm{CPY} 404 . t x t$ & unknown & Seq: 30 & 31-OCT-11 & 11:23 \\
\hline
\end{tabular}

TRIPs-plus type mechanisms, outlined the basic "minimum-rights" problem regarding TRIPs principles:

The Agreement [TRIPS] could not be divorced from the objectives and principles set out in its Articles 7 and 8. Enforcement of IPRs in disregard of these objectives and principles and efforts to enshrine new, maximalist TRIPS-plus enforcement provisions in other multilateral forums would seriously undermine the delicate balance in the TRIPS Agreement and raise systemic issues, particularly for developing countries. ${ }^{121}$

The provisions listed above form a potential basis for achieving that balance in the TK realm, and provide grounds for objection to certain TK protections.

\section{Preamble, Principles and Objectives of TRIPs}

Setting the tone for the agreement is the preamble of TRIPs, which begins by stating a basic goal "to reduce distortions and impediments to international trade."122 Far from a one-sided minimum-rights tone, the preamble makes clear that TRIPs' main goal is to reduce impediments to trade; the protection of IPRs is merely a means to that end.123 Further, the preamble itself recognizes that measures to enforce IPRS may themselves become obstacles to trade. Standing alone the preamble likely has little impact on national or regional TK protections, but its tenor will inform the interpretation of more substantive restrictions, as shown below.

Article 7 of TRIPs provides the general objectives of the agreement. Of importance here are the provisions which provide that "protection and enforcement of intellectual property rights should contribute to the pro-

121 World Trade Org., Council for the Trade-Related Aspects of Intellectual Property Rights, Minutes of Meeting Held in the Centre William Rappard 8-9 June 2009 II 135 (WTO Doc. IP/C/M/60). The Indian delegate took the position that "In addition to laying certain minimum standards, the TRIPs Agreement also provides 'ceilings' some of which are mandatory and clearly specified in the TRIPs Agreement. Moreover, the TRIPs Agreement has achieved a very careful balance of the interests of the right-holders on the one hand, and societal interests, including development-oriented concerns, on the other." Id.

122 TRIPs Agreement preamb. Note that Article 31 of the Vienna Convention on the Law of Treaties, 1155 U.N.T.S. 331, May 22, 1969, entered into force Jan. 20, 1980 [hereinafter VCLT], provides that "A treaty shall be interpreted in good faith in accordance with the ordinary meaning to be given to the terms of the treaty in their context and in the light of its objective and scope.... The context for purposes of the interpretation of the treaty shall comprise, in addition to the text, including its preamble and annexes ...." VCLT art. 31.

123 This interpretation is also shared by United Nations Conference on Trade and Development \& International Centre for Trade and Sustainable Development, Resource Book on TRIPS and Development 10 (2005) [hereinafter RESOURCE BOOK ON TRIPS]. 


\begin{tabular}{lllll}
\hline |ljciprod01 $\mid$ productn $\backslash \mathrm{C} \backslash \mathrm{CPY} \backslash 58-4 \backslash \mathrm{CPY} 404 . t x t$ & unknown & Seq: 31 & 31-OCT-11 & 11:23 \\
\hline
\end{tabular}

motion of technological innovation and to the transfer and dissemination of technology, to the mutual advantage of producers and users of technological knowledge and in a manner conducive to social and economic welfare, and to a balance of rights and obligations." 124 Like the preamble, these objectives standing alone may not weigh heavily against positive TK protections, but Article 7 does point out some important interpretative points - namely that both producers and users should be considered in creating a "balance of rights and obligations." 125

Article 8 of TRIPs (listing the principles of the agreement) provides that "appropriate measures may be needed to prevent the abuse of intellectual property rights by right holders or the resort to practices which unreasonably restrain trade or adversely affect the international transfer of technology."126 Again, one can see an interpretative stance on TRIPs that favors limitations on unilateral expansions of intellectual property rights.

\section{Procedural Enforcement}

The preamble to TRIPs states that the agreement intends "to ensure that measures and procedures to enforce intellectual property rights do not themselves become barriers to legitimate trade." 127 With this basic goal in mind, some recent pushes for more stringent border control measures (in particular, the draft text of Anti-Counterfeiting Trade Act ("ACTA")) have been met with the response that the procedural rules of TRIPs simply do not allow for such invasive conduct. ${ }^{128}$ Some of those same arguments against TRIPs-plus enforcement are applicable to the expansion of TK protections.

TRIPs basic procedural safeguards - which are interpreted with the preamble, principles, and objectives in mind - require that "rights holders" have access to "fair and equitable procedures" in judicial proceedings concerning intellectual property covered by TRIPs. ${ }^{129}$ From this basic

124 TRIPs Agreement art. 7.

125 Id.

126 Id. art. 8.

127 Id. Preamble.

128 See Denis Borges Barbosa, Untoward Restrictions to Trade and Abuses of Intellectual Property Rights: A Brazilian Perspective - An ACTA Paper for WCL Meeting (unpublished manuscript, 2010), available at http://ssrn.com/ abstract $=1628744$.

129 TRIPs Agreement arts. 41-42. The full text of the Article 42 is as follows: Members shall make available to right holders civil judicial procedures concerning the enforcement of any intellectual property right covered by this Agreement. Defendants shall have the right to written notice which is timely and contains sufficient detail, including the basis of the claims. Parties shall be allowed to be represented by independent legal counsel, 
\begin{tabular}{lllll}
\hline |ljciprod01 $\mid$ productn $\backslash \mathrm{C} \backslash \mathrm{CPY} \backslash 58-4 \backslash \mathrm{CPY} 404 . t x t$ & unknown & Seq: 32 & 31-OCT-11 & 11:23 \\
\hline
\end{tabular}

declaration of rights spring three questions regarding whether TK expressions protections are subject to this section: (1) are users of TK expressions "rights holders" for purposes of Article 42; (2) are those rights "concerning the enforcement of any intellectual property right covered by" TRIPs; and (3) does the deprivation of rights violate TRIPs procedural safeguards contained in Articles 41 and 42?

Whether users of TK expressions are rights holders is a question that is at least partially answered. The WTO has supported a bi-directional reading of the term "rights holders" in Article 42. In the United States Section 211 dispute (regarding trademark dispute procedures), the WTO appellate body concluded that "[p]ursuant to the first sentence of Article 42 , civil judicial procedures must be made available to 'right holders' of intellectual property rights covered by the TRIPS Agreement so as to enable them to protect those rights against infringement."130 The appellate body rejected the United States' contention that "rights holders" were limited to the owner of the intellectual property. It went on to agree with the panel decision in defining the term " 'right holders' as persons who have the legal capacity to assert rights." 131 The WTO Appellate body recognized implied, reciprocal rights for users, stating that "[w]here the TRIPS Agreement confers rights exclusively on 'owners' of a right, it does so in express terms.... By contrast, the term 'right holders' within the meaning of Article 42 also includes persons who claim to have legal standing to assert rights. This interpretation is also borne out by the fourth sentence of Article 42, which refers to "parties." 132

Falling within the above definition of "rights holder" should be easy for those who have already made use of now-protected TK expressions, especially where the user adapted such expressions believing they were in the public domain or otherwise freely accessible. The WTO equated the term "rights holder" to mean a person who has legal standing to assert rights. ${ }^{133}$ Standing in the federal courts of the United States, for example, must be demonstrated by a concrete and particularized harm, caused by the plaintiff, which is judicially redressable. ${ }^{134}$ In the United Kingdom,

and procedures shall not impose overly burdensome requirements concerning mandatory personal appearances. All parties to such procedures shall be duly entitled to substantiate their claims and to present all relevant evidence. The procedure shall provide a means to identify and protect confidential information, unless this would be contrary to existing constitutional requirements.

130 United States - Section 211 Omnibus Appropriations Act of 1998, Ab-2001-7, 131 Id. Report of the Appellate Body II 217 (WT/DS176/AB/R) (Jan. 2, 2002).

132 Id.

133 Id.

134 See, e.g., Lujan v. Defenders of Wildlife, 504 U.S. 555 (1992). 


\begin{tabular}{lllll}
\hline |ljciprod01 $\mid$ productn $\backslash \mathrm{C} \backslash \mathrm{CPY} \backslash 58-4 \backslash \mathrm{CPY} 404 . t x t$ & unknown & Seq: 33 & 31-OCT-11 & 11:23 \\
\hline
\end{tabular}

where standing requirements are not burdened by the same constitutional "case or controversy" strictures, the requirements are even lower - a mere showing of "sufficient interest" is required. ${ }^{135}$ Asserting the defense that use of a particular work was or is allowed because the work was in the public domain should be enough for standing purposes, and should suffice for purposes of fair and equitable access to Article 42 procedural rights. Indeed, the WTO declares that that "[c]ivil judicial procedures would not be fair and equitable if access to courts were not given to both complainants and defendants." 136

The argument is even stronger for those who have created derivative or transformative works based on TK expressions, not only because those users are rights holders as users of TK, but also because they hold independent rights as holders of copyright. In countries where the derivative works or adaptations are regulated by a national copyright board, the creators of these new works may have independent legal standing as rights holders over TRIPs-covered works. ${ }^{137}$

Of course, asserting what essentially amounts to a defense of the use of one type of intellectual property (copyright) is not always a defense to all other laws regulating that work. TRIPS procedural safeguards are only triggered when the legal action is "concerning the enforcement of any intellectual property right covered by [TRIPs]." 138 Intellectual property is regularly controlled through laws other than copyright or patent. For instance, U.S. law may protect knowledge with both copyright and trade secrets law. Suppose Corporation X owned a compilation of facts regarding its production procedures, and Corporation $\mathrm{Y}$ acquired and published those procedures. Typically, this type of work is not protected by U.S.

135 Supreme Court Act 1981 § 31(3) (Eng.) (requiring for High Court review "sufficient interest in the matter to which the application relates").

136 United States - Section 211 Omnibus Appropriations Act of 1998, Ab-2001-7, Report of the Appellate Body II 217 (WT/DS176/AB/R) (Jan. 2, 2002). Note that the Appellate Body goes on the say that those procedures would not be fair and equitable if they did not allow access for both complainants and defendants "who purport to be owners of an intellectual property right." Id. While this may at first be troublesome in the present context since users of public domain materials do not assert that they are the "owner" of the right, but rather, are permitted to use the particular work. However, given the language earlier in the Section 211 decision regarding broad access to procedures, it is probably safe to say that the language referencing "ownership" is merely an example of those who have procedural rights available, and is not a limitation on that group.

137 Some countries with provisions regulating the creation of derivative works include Burkina Faso, Law No. 032-99/AN on the Protection of Literary and Artistic Property art. 92; and Nigeria, Copyright Act, Chapter 68 Laws of the Federation of Nigeria 1990 arts. 28-29. Others have similar provisions.

138 TRIPs Agreement art. 42. 
\begin{tabular}{lllll}
\hline |ljciprod01 $\mid$ productn $\backslash \mathrm{C} \backslash \mathrm{CPY} \backslash 58-4 \backslash \mathrm{CPY} 404 . t x t$ & unknown & Seq: 34 & 31-OCT-11 & 11:23 \\
\hline
\end{tabular}

copyright because it does not have the required "modicum of originality" — copyright only extends to original expressions, and not facts. ${ }^{139}$ But trade secret protections may still provide protection of those facts, despite the valid defense that the underlying work is not protected by copyright. ${ }^{140}$ One critical difference between trade secret protection and TK protections, however, is that TRIPS explicitly provides for trade secret protection (Article 39 - Protection of Undisclosed Information), ${ }^{141}$ but says nothing about TK protections. Thus, trade secrets may still be subject to TRIPS procedural safeguards, but their application to TK protections may be more of an open question.

Article 42 only provides procedural protections to rights holders of "intellectual property right[s] covered by this Agreement." 142 Article 1 notes that for purposes of the agreement, "the term 'intellectual property' refers to all categories of intellectual property that are subject to Sections 1 through 7 of Part II." 143 Whether TK protections can be cast as fitting within one of the categories of intellectual property rights is a serious question. The categories of IPRs covered by TRIPs include copyright and related rights, trademarks, geographical indications, industrial designs, patents, layout-designs (topographies) of integrated circuits, and undisclosed information. ${ }^{144}$ As discussed in Part II, TK expressions do not fall neatly into any of these categories, and in fact are contentious because their underlying justification is so different from these categories of works. TK protections of expressions are often cast as sui generis, ${ }^{145}$ and even where they are included within a greater statutory copyright scheme (as is

139 Feist Publ'ns, Inc. v. Rural Tel. Serv. Co., 499 U.S. 340 (1991).

140 To qualify for trade secret protection, states law generally requires that the information is secret, that reasonable efforts are made to maintain secrecy. The 1979 Uniform Trade Secret Protection Act provides in part that:

"Trade secret" means information, including a formula, pattern, compilation, program, device, method, technique, or process, that:

(i) derives independent economic value, actual or potential, from not being generally known to, and not being readily ascertainable by proper means by, other persons who can obtain economic value from its disclosure or use, and

(ii) is the subject of efforts that are reasonable under the circumstances to maintain its secrecy.

3 Trade Secrets Law, appendix A1 (2010) (1979 Uniform Trade Secrets Protection Act $\$ 1$ ).

141 TRIPs Agreement art. 39.

142 Id. art. 42.

143 Id. art. 1(2).

144 See generally id.

145 Meaning "of its own kind." See, e.g., Dutfield, supra note 13, at 240 (discussing the conceptually different nature of TK and TK protections); see also Legislative Texts on the Protection of Traditional Cultural Expressions (Expressions of Folklore) (TCEs), World Intell. Prop. Org., http://www.wipo. 


\begin{tabular}{lllll}
\hline |ljciprod01 $\mid$ productn $\backslash \mathrm{C} \backslash \mathrm{CPY} \backslash 58-4 \backslash \mathrm{CPY} 404 . t x t$ & unknown & Seq: 35 & 31-OCT-11 & 11:23 \\
\hline
\end{tabular}

often the case) TK protections are still beyond the usual authorship requirements of "copyright" as defined in TRIPs, and therefore outside of the categories of IP covered by TRIPs procedural safeguards. ${ }^{146}$

Even where TK expression and their protective legislative schemes are outside of the categories of intellectual property covered by TRIPs, users of TK expressions may not be. Although the Article 1 definition of "categories of intellectual property" has been suggested to be a limiting provision of the agreement (therefore, to be read narrowly), ${ }^{147}$ the preamble, principles, and objectives of TRIPs all suggest that the users of intellectual property, otherwise unprotected by TRIPs, may have standing.

For users who have merely reproduced or distributed TK expressions, it is harder to argue for the application of protections; for these users to fall within the terms of Article 42, the WTO would need to find that the categories of intellectual property covered by TRIPs includes not just positive copyright protection, but also some negative protection - i.e., some area for inclusion where users operating under the presumption that copyright or other TRIPs IP rights clearly does not apply. This type of argument may be a stretch because it would essentially require reading some components of the public domain (Western style) into TRIPs. ${ }^{148}$ But a much more tenable argument can be made for the inclusion of users who have used TK-protected materials to produce derivative or adapted works that $d o$ have authorship components, and therefore are covered by copyright. Because many positive TK protections include express restrictions on the creation of derivative works, ${ }^{149}$ these users (as rights holders)

int/tk/en/laws/folklore.html\#special (last visited Dec. 5, 2010) (listing sui generis legal provisions protecting TCEs).

146 See supra note 26 (explaining how TRIPs incorporates the Berne Convention standards for authorship in copyright). Indeed, much of the discussion at WIPO presumes that TK is outside the scope of TRIPs. See REsource BoOK ON TRIPS, supra note 123, at 46 n.106 (noting proposals for review for "the situation regarding traditional knowledge (TK) and folklore, as matters presumably outside the scope of the existing categories of intellectual property").

147 See id.at 45 ("Since Article 1.2 is expressed in the form of limitation, there is good reason to conclude that the categories of intellectual property should bear a reasonably close relationship to the subject matters enumerated in Sections 1 through 7 of Part II.").

148 Although the practical creation of this sort of public domain is recognized as a result of the creation of TRIPs, there has been no suggestion that TRIPs actually works to protect it. See Chander \& Sunder, supra note 54, at 1346.

149 Some countries with provisions regulating the creation of derivative works include Burkina Faso, Law No. 032-99/AN on the Protection of Literary and Artistic Property art. 92; and Nigeria, Copyright Act, ch. 68, Laws of the Federation of Nigeria 1990, arts. 28-29. Others have similar provisions. See also World. Intellectual Prop. Org., Scoping Study on Copyright and Related Rights and the Public Domain (May 7, 2010) (CDIP/4/ 
would bring those TK protections under scrutiny as potential violations of Article 42 procedural safeguards.

Assuming that at least some users of TK expressions are rights holders of intellectual property for purposes of Article 42, one must then question whether any procedural rights are actually violated. Article 42 contains the basic requirement that rights holders have access to fair and equitable procedures, which include access to civil judicial remedies. Furthermore, Article 41 provides that procedures not be "unnecessarily complicated or costly," 150 that decisions on the merits be based on evidence where parties have the opportunity to be heard, ${ }^{151}$ and that parties have an opportunity for judicial review of administrative decisions. ${ }^{152}$

The procedural safeguards noted above indicate that certain national protections of TK expressions may run afoul of TRIPs, especially when considered in line with other TRIPs maximums, such as the WTO-standard "most favored nation" treatment or the requirement that foreigners receive the same treatment as citizens. ${ }^{153}$ As an example, consider the TK protections in Burkina Faso's copyright law. The Burkina Faso provision relating to folklore provides that:

The creation of works derived from expressions of traditional cultural heritage which are part of national heritage such as adaptations, translations, transcriptions, collections with or without agreement, and other alterations shall be free of charge for the people of Burkina Faso. Such creation shall be subject to authorization from the collective management organization for foreigners. The creation, after its production, shall be declared to the collective management organization. ${ }^{154}$

Under this section, the creation of works derived from traditional expressions is explicitly allowed for the people of Burkina Faso, but is subject to authorization from the Burkina Faso Collective Management Organization for foreigners. Considering Article 42, the foreign creator of a derivative work would fall under the protections of this section because the creator is a 'rights holder' of intellectual property (here, as an author) covered by TRIPs. ${ }^{155}$ It is immediately evident that this section does not afford equal treatment of nationals and foreigners, potentially violating

3/REV./STUDY/INF/1), available at http://www.wipo.int/edocs/mdocs/ mdocs/en/cdip_4/cdip_4_3_rev_study_inf_1.pdf.

150 TRIPs Agreement art. 41(2).

151 Id. art. 41(3).

152 Id. art. 41(4).

$153 I d$. art. 3 (national treatment); id. art. 4 (most favored nation treatment).

154 See Burkina Faso Law No. 032-99/AN on the Protection of Literary and Artistic Property art. 92.

155 In fact, because the Bukina Faso section likely violates the Article 3 (national treatment), one would not need to rely on TRIPs procedural safeguards to contest this law. 


\begin{tabular}{lllll}
\hline |ljciprod01 $\mid$ productn $\backslash \mathrm{C} \backslash \mathrm{CPY} \backslash 58-4 \backslash \mathrm{CPY} 404 . t x t$ & unknown & Seq: 37 & 31-OCT-11 & 11:23 \\
\hline
\end{tabular}

TRIPs Article 3 ("Each Member shall accord to the nationals of other Members treatment no less favourable than that it accords to its own nationals with regard to the protection of intellectual property."). ${ }^{156}$

Another interesting example comes from Malawi, which has a similar provision, but with explicit reference to judicial review which provides that "in granting or refusing to grant an application for authorization under this Part, the Minister shall not be required to assign any reasons and his decision shall be final and not subject to appeal to, or review or question by, any court." 157 This contradicts the procedural norms found in TRIPs Article 41.4, which explicitly provides for an opportunity for review. ${ }^{158}$ Of course, there are other TK protection regimes which do not contain such blatantly discriminatory provisions. Countries like Algeria, for example, simply provide that the nation's National Bureau of Copyright has authority to "control the extent of appropriate utilization" of TK expressions. ${ }^{159}$ Whether such provisions would offend TRIPs procedural rules depends largely on whether there are guiding regulations which explain the agency's authority to control the use of TK expressions, and whether there is any right for users to initiate judicial review. As a broader, and more theoretical point, one might argue that provisions like those found in Algeria's law are violations of TRIPs procedural norms not because they do not allow for judicial review, but because the substantive provisions are so radically different in their construction of users' rights in terms of a construction of the copyright-less public domain so as to constitute a deprivation of procedural rights. Further review of individual national TK protection laws would be necessary to evaluate if and how other TK protections are contrary to TRIPs procedural safeguards.

\section{CONCLUSION}

In one sense, all of copyright law is a trade restriction; it grants rights - and value - to one group (or one single author), at the expense of another. But in Western realms, the rights-holder group is relatively small, and rights holders make identifiable individual contributions to the work. In this system, there is some relationship between the incentive to create the work and the reward of IPR protection. With traditional knowledge protections, however, ownership is often thought to extend to all members of a particular community, merely by membership in that community.

156 Examined through the lens of GATT Article 20's "disguised restriction on trade" provision, one cannot help but wonder how much more explicit a provision could be before falling within that article's prohibitions.

157 See Malawi Copyright Act, 1989 art. 28(1) (No. 9, of Apr. 26, 1989).

158 TRIPs Agreement art. 41(4) ("Parties to a proceeding shall have an opportunity for review by a judicial authority of final administrative decisions.").

159 Algeria Droits d'auteur, Ordonnance art. 141 (19/07/2003 - 1424, n 03-05). 


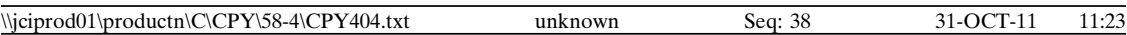

Where rights are granted by virtue of a membership in a community, serious questions arise regarding the concept of authorship (which may be largely non-existent in this context), and the scope of rights granted to communities as "public" beneficiaries of the "public domain." Because the scope of these TK rights is so broad - in particular, where they are appropriated and managed by States - there may be a potential for conflict under existing international agreements. This conflict is particularly ripe as between countries such as the United States, who view IPRs as primarily issues of property rights and access rights, and countries in the developing world that do not. This tension between countries like the United States and the developing world have been well recognized, but this friction has typically been constructed as political or ideological, and thus amenable to political "work-arounds."

One commentator suggests, for example, that the "vigorous and uniform protection of folklore" may be achieved outside national or regional boundaries and in places such as the United States via a "regional agency with authority to institute infringement actions abroad and to serve as the conduit for processing requests to use folklore as well as distributing compensation collected for the use of folklore." 160 In other forums, a modification of WTO texts to accommodate protection of TK protections has been suggested. This article highlights that protections of TK expressions, even as they exist now in national legislation, not only conflict with the information-policy norms of Western countries, but may also conflict with the terms of international trade agreements such as TRIPs and GATT. It is important for policy makers and delegates from the United States and the European Community to fully appreciate how fundamentally different some TK protection schemes are, even deviating from the very few agreed-upon IPR "maximums" contained in TRIPs. Understanding how and why these protections stray from TRIPs will give U.S. and European Community policy makers guidance on where they should direct their efforts in the ongoing negotiations for expanded international TK protections.

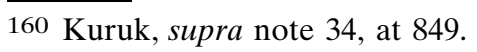

